\title{
Review \\ Severe Plastic Deformation and Phase Transformations in High Entropy Alloys: A Review
}

\author{
Boris B. Straumal ${ }^{1,2, *}$, Roman Kulagin ${ }^{1}$, Brigitte Baretzky ${ }^{1}$, Natalia Yu. Anisimova ${ }^{2,3}{ }^{(0)}$, \\ Mikhail V. Kiselevskiy ${ }^{2,3}$, Leonid Klinger ${ }^{4}$, Petr B. Straumal ${ }^{5}\left(\mathbb{D}\right.$, Olga A. Kogtenkova ${ }^{2}$ and Ruslan Z. Valiev ${ }^{6}(\mathbb{D}$
}

1 Karlsruhe Institute of Technology (KIT), Institute of Nanotechnology, Hermann-von-Helmholtz-Platz 1, 76344 Eggenstein-Leopoldshafen, Germany; roman.kulagin@kit.edu (R.K.); brigitte.baretzky@kit.edu (B.B.)

2 Chernogolovka Scientific Center of the Russian Academy of Sciences, Lesnaja Str. 9, 142432 Chernogolovka, Russia; n_anisimova@list.ru (N.Y.A.); kisele@inbox.ru (M.V.K.); kogtenkova@issp.ac.ru (O.A.K.)

3 N.N. Blokhin National Medical Research Center of Oncology, Ministry of Health, Russian Federation (N.N. Blokhin NMRCO), 115478 Moscow, Russia

4 Department of Materials Science and Engineering, Technion-Israel Institute of Technology, Haifa 3200003, Israel; klinger@technion.ac.il

5 Baikov Institute of Metallurgy and Materials Science, Russian Academy of Sciences, Leninsky Prosp. 49, 119334 Moscow, Russia; straumal.peter@yandex.ru

6 Institute for Physics of Advanced Materials, Ufa State Aviation Technical University (USATU), Karl Marx Str. 12, 450000 Ufa, Russia; ruslan.valiev@ugatu.su

* Correspondence: boris.straumal@kit.edu

Citation: Straumal, B.B.; Kulagin, R.; Baretzky, B.; Anisimova, N.Y.;

Kiselevskiy, M.V.; Klinger, L.; Straumal, P.B.; Kogtenkova, O.A.; Valiev, R.Z. Severe Plastic Deformation and Phase Transformations in High Entropy Alloys: A Review. Crystals 2022, 12, 54. https://doi.org/10.3390/ cryst12010054

Academic Editors: Xusheng Yang, Honghui Wu and Jiaming Zhu

Received: 12 December 2021 Accepted: 28 December 2021 Published: 31 December 2021

Publisher's Note: MDPI stays neutral with regard to jurisdictional claims in published maps and institutional affiliations.

Copyright: () 2021 by the authors Licensee MDPI, Basel, Switzerland. This article is an open access article distributed under the terms and conditions of the Creative Commons Attribution (CC BY) license (https:// creativecommons.org/licenses/by/ $4.0 /)$.

\begin{abstract}
This review discusses an area of expertise that is at the intersection of three large parts of materials science. These are phase transformations, severe plastic deformation (SPD), and highentropy alloys (HEA). First, SPD makes it possible to determine the borders of single-phase regions of existence of a multicomponent solid solution in HEAs. An important feature of SPD is that using these technologies, it is possible to obtain second-phase nanoparticles included in a matrix with a grain size of several tens of nanometers. Such materials have a very high specific density of internal boundaries. These boundaries serve as pathways for accelerated diffusion. As a result of the annealing of HEAs subjected to SPD, it is possible to accurately determine the border temperature of a single-phase solid solution area on the multicomponent phase diagram of the HEA. Secondly, SPD itself induces phase transformations in HEAs. Among these transformations is the decomposition of a single-phase solid solution with the formation of nanoparticles of the second phase, the formation of high-pressure phases, amorphization, as well as spinodal decomposition. Thirdly, during SPD, a large number of new grain boundaries (GBs) are formed due to the crystallites refinement. Segregation layers exist at these new GBs. The concentration of the components in GBs differs from that in the bulk solid solution. As a result of the formation of a large number of new GBs, atoms leave the bulk solution and form segregation layers. Thus, the composition of the solid solution in the volume also changes. All these processes make it possible to purposefully influence the composition, structure and useful properties of HEAs, especially for medical applications.
\end{abstract}

Keywords: high entropy alloys; severe plastic deformation; precipitation; phase transitions; phase diagrams

\section{Introduction}

This paper is at the crossroads of three large areas of materials science. These are phase transformations, severe plastic deformation, SPD (and, in particular, high-pressure torsion, HPT), as well as multicomponent alloys without the main component (they are also called high-entropy alloys, HEAs). Each of these areas is truly immense: thousands, and in the case of phase transformations, dozens of thousands of articles are devoted to them. Nevertheless, the area of their intersection is not too large and is quite accessible 
for presentation in a small review. In this case, we are not talking about their simple, mechanical superposition. All three areas, intersecting, do not just overlap one another, but cause something like mutual fertilization (or pollination). It seems to us that in the near future such combined studies will arise great interest and lead not only to unusual results but also to serious advances in materials science.

\section{The Borders of the Single-Phase Region of Existence of HEAs}

An important feature of HEAs is that the atoms of five, six, or more components included in them form a single, disordered and homogeneous solid solution [1-4]. This solid solution is formed already during solidification, and after homogenizing annealing, it loses all residual inhomogeneities. However, an essential question arises: how wide is the temperature range in which this homogeneous solid solution remains thermodynamically stable? In other words, below what temperature do precipitates of the second phase begin to appear in the solid solution? It would seem that the answer to this question is very easy: you only need to carry out long-term annealing at different temperatures, and then measure and interpret the X-ray diffraction (XRD) patterns. However, if the formation of second phase precipitates occurs by the volume diffusion and is determined by its rate, then such annealing needs a very long time. For example, a similar direct experiment for the equiatomic CoCrFeMnNi Cantor alloy, which has a face-centered (fcc) lattice of the $\gamma$-phase, was carried out in just one work [5]. The authors of [5] homogenized samples of the Cantor alloy at $1200^{\circ} \mathrm{C}$ for $2 \mathrm{~h}$, and then annealed at 900,700 , and $500{ }^{\circ} \mathrm{C}$ for 500 days After annealing at $900{ }^{\circ} \mathrm{C}$, the alloy remained homogeneous. At a temperature of $700{ }^{\circ} \mathrm{C}$, particles of the $\sigma$-phase rich in chromium were formed in it. However, these particles appeared mainly at the grain boundaries (GBs) of the fcc matrix (see Figure 1). At $500{ }^{\circ} \mathrm{C}$, in addition to the particles of the $\sigma$-phase, the precipitates with a body-centered cubic (bcc) lattice, rich in nickel and manganese, appeared at GBs as well (see Figure 2).
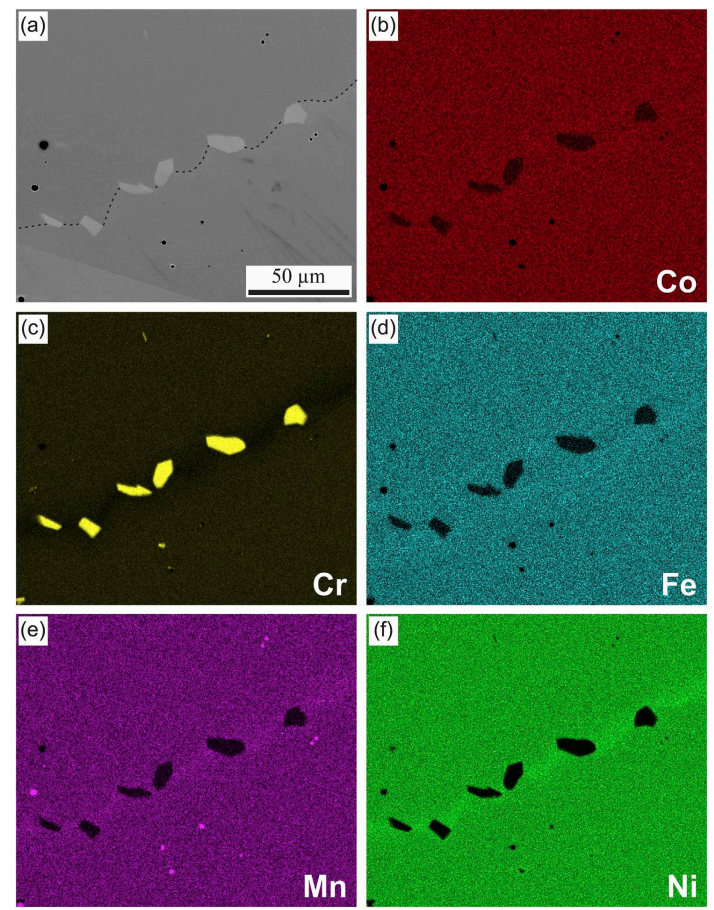

Figure 1. Microstructure of the CrMnFeCoNi HEA after a 500-day anneal at $700{ }^{\circ} \mathrm{C}$. (a) Representative BSE image showing the presence of blocky faceted precipitates on a grain boundary. (b-f) Elemental energy dispersive $\mathrm{X}$-ray (EDX) maps showing significant enrichment of $\mathrm{Cr}$ in the precipitates (relative to its concentration in the HEA) and depletion of all other elements. The dashed line delineating the GB in (a) was added as a guide for the eye. There appears to be a slight enrichment of Mn and Ni near the GB in (e,f). Reprinted with permission from Ref. [5]. Copyright 2016 Elsevier. 

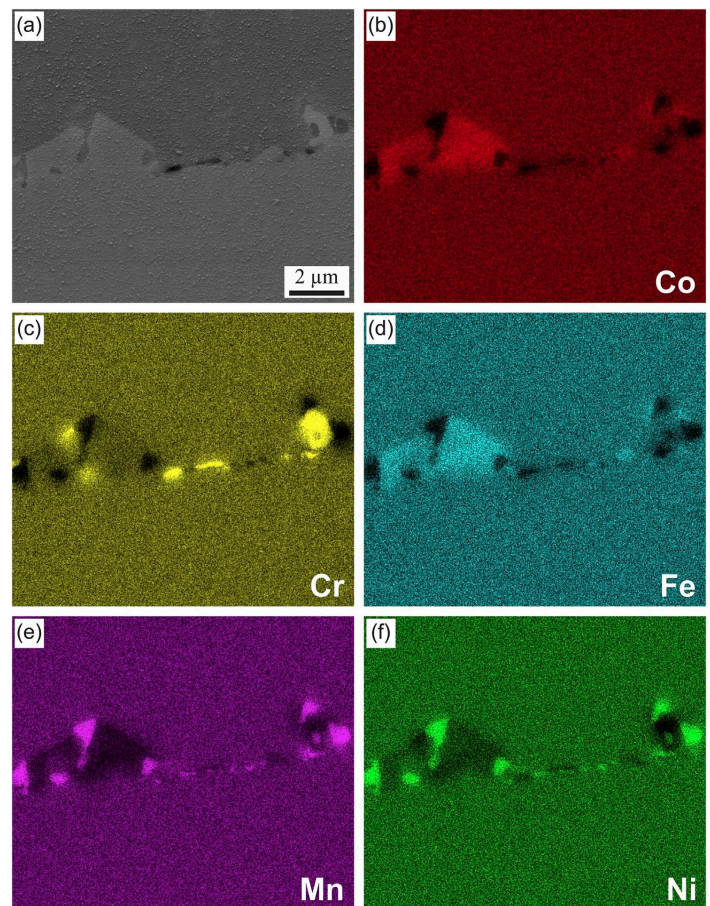

Figure 2. Microstructure of the $\mathrm{CrMnFeCoNi} H E A$ after a 500 -day anneal at $500{ }^{\circ} \mathrm{C}$. Representative BSE image showing multiple precipitates on a GB (a) and elemental EDX maps showing the distribution of $\mathrm{Co}(\mathbf{b}), \mathrm{Cr}(\mathbf{c}), \mathrm{Fe}(\mathbf{d}), \mathrm{Mn}(\mathbf{e})$ and $\mathrm{Ni}(\mathbf{f})$ in the area shown in (a). Reprinted with permission from Ref. [5]. Copyright 2016 Elsevier.

Fortunately, the experiments to determine the borders of the existence of a singlephase solid solution in HEAs can be significantly facilitated if samples with fine grains and, accordingly, a large specific GB area is created. In this case, the growth of second phase precipitates will be controlled by GB rather than bulk diffusion, and the thermodynamic equilibrium can be achieved much faster. Small grains in HEAs can be created using the so-called severe plastic deformation (SPD), and in particular, the high-pressure torsion (HPT), equal channel angular pressing (ECAP), or hot-pressing sintering [6-17]. Thus, the TiZrNbMoV and NbTiAlTaV HEAs after hot-pressing sintering contained in addition to the solid solution a small number of complex metal compounds like $\mathrm{Mo}_{9} \mathrm{Ti}_{4}, \mathrm{Nb}_{9} \mathrm{Ti}_{4}$, or $\mathrm{Mo}_{2} \mathrm{Zr}$ [17]. In a number of studies, Kantor's alloys were deformed using HPT or ECAP. After SPD, the resulting polycrystals with a grain size of 10-20 nm was annealed for a relatively short time at different temperatures in the range from 200 to $900{ }^{\circ} \mathrm{C}[5,18-24]$. Simultaneously with the growth of grains, particles of the $\sigma$-phase and bcc-phase rapidly appeared at GBs in such samples. Figure 3 shows typical XRD patterns of Cantor alloy after HPT (6 GPa, $5 \mathrm{rpm}, 1 \mathrm{rpm}$ ) and short annealing (60 $\mathrm{min})$ [20]. 


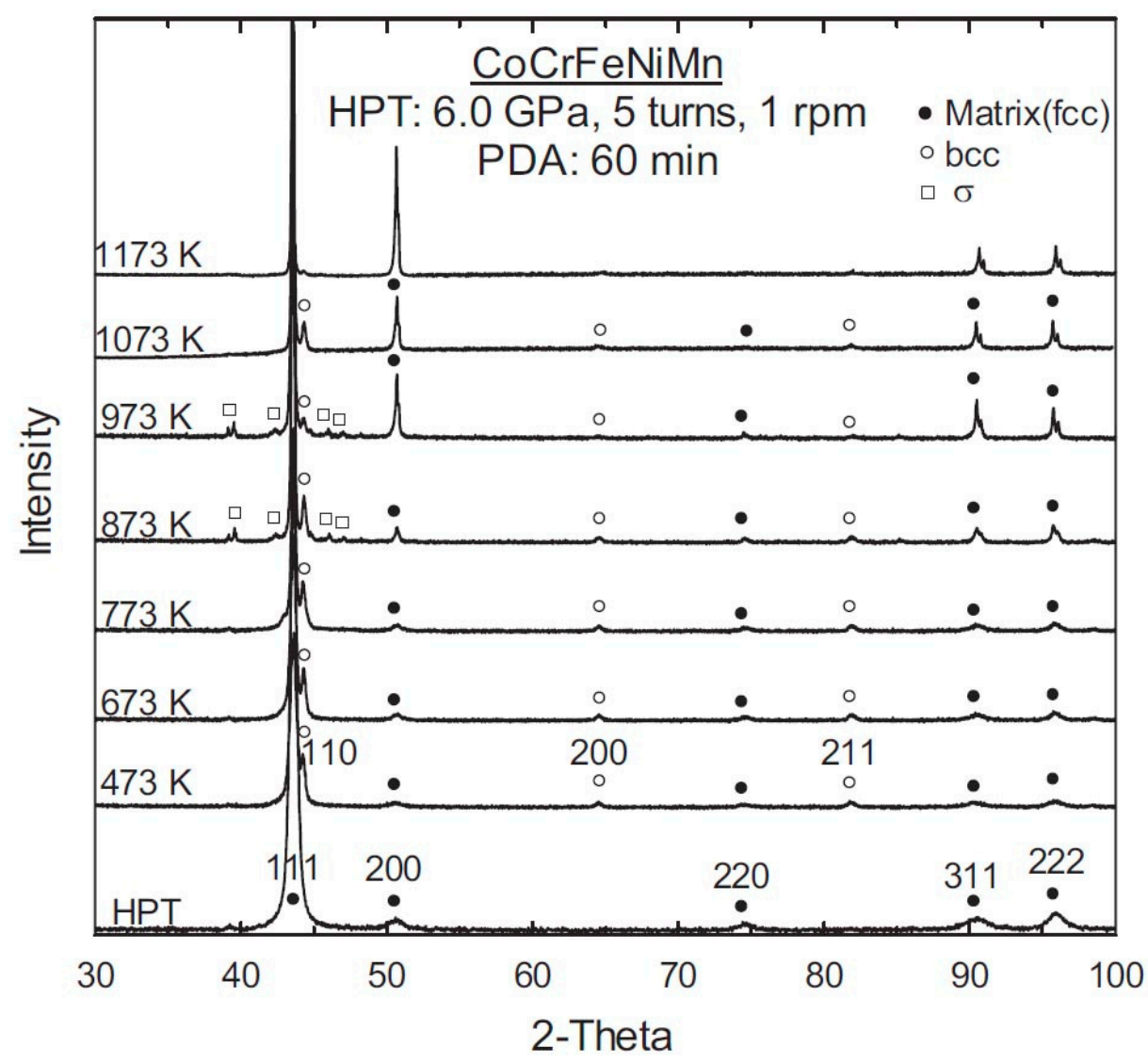

Figure 3. XRD patterns near the edges of the disk after HPT processing followed by post-deformation annealing at $200-900{ }^{\circ} \mathrm{C}$ for $60 \mathrm{~min}$. Reprinted with permission from Ref. [20]. Copyright 2016 Elsevier.

Figure 4 summarizes the results of such works [5,18-24]. It is clearly seen from the graph that a bcc-phase exists in the Cantor alloy at temperatures below $800{ }^{\circ} \mathrm{C}$. The bccphase was observed even upon annealing at $200{ }^{\circ} \mathrm{C}$. Thus, the region of existence of a bcc-phase does not have an obvious lower temperature border. In contrast, the $\sigma$-phase exists in a limited temperature range. The $\sigma$-phase appears at about $800{ }^{\circ} \mathrm{C}$ and disappears again below $450{ }^{\circ} \mathrm{C}$. A similar phenomenon is often observed for $\sigma$-phases in binary alloys (for example, in iron-chromium ones). In binary alloys, the $\sigma$-phase usually arises between metals, one of which has a bcc lattice, and the other has a fcc lattice, and the difference in atomic diameters of the metals included in the $\sigma$-phase does not exceed $8 \%$. The $\sigma$-phase has a complex tetragonal crystal lattice with a unit cell of 30 atoms, similar to the crystal lattice of uranium. The $\sigma$-phase is usually characterized by a wide homogeneity region. 


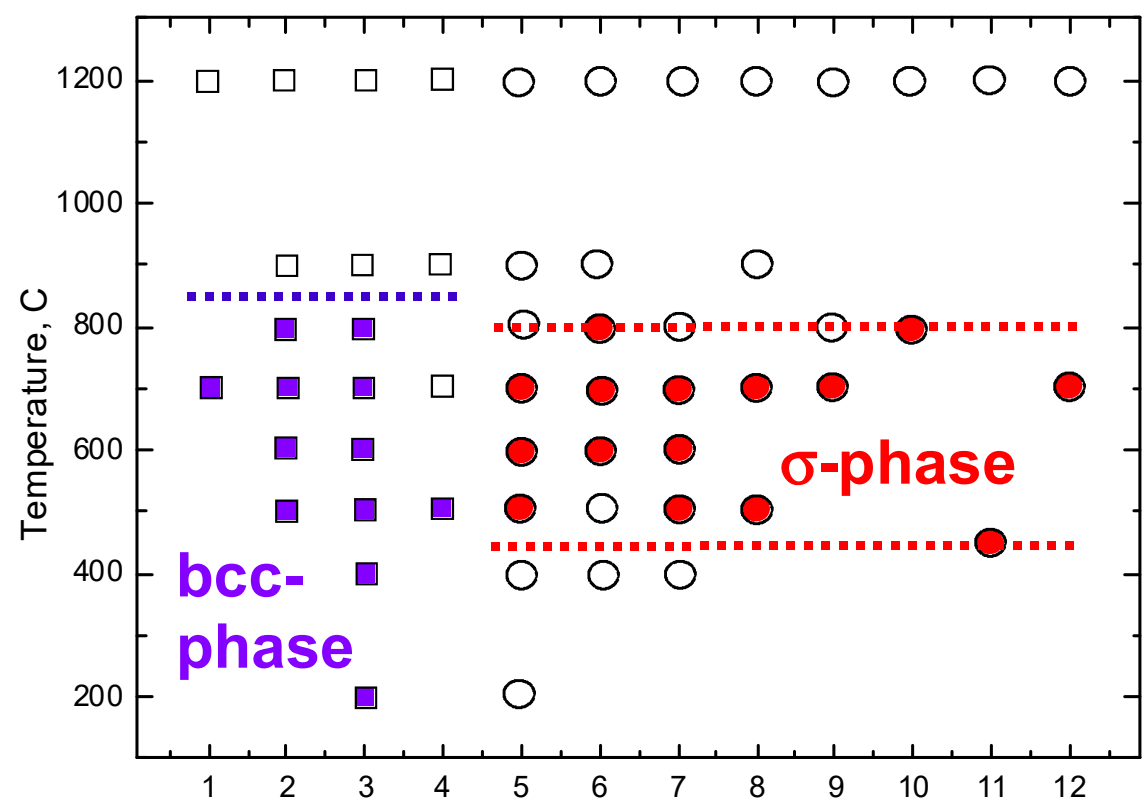

Figure 4. The diagram shows the presence (filled symbols) or absence (open symbols) for bcc-phase (squares) and $\sigma$-phase (circles) at various temperatures. The diagram is constructed using the data of Refs. [5,18-24]. The numbers on the horizontal axis denote the literature source for the data: 1 [18], 2 [19], 3 [20], 4 [5], 5 [20], 6 [19], 7 [21], 8 [5], 9 [18], 10 [22], 11 [23], 12 [24].

It is interesting that in the modified Cantor alloy $\mathrm{Co}_{20} \mathrm{Cr}_{26} \mathrm{Fe}_{20} \mathrm{Mn}_{20} \mathrm{Ni}_{14}$ where the ratio of nickel and chromium is changed, the $\sigma$-phase exists up to higher temperatures $[25,26]$. In particular, it is observed after annealing at $1050^{\circ} \mathrm{C}$ for $24 \mathrm{~h}$ [26]. In another modified Cantor alloy, $\mathrm{Co}_{40} \mathrm{Cr}_{40} \mathrm{Fe}_{10} \mathrm{Mn}_{10}$, the $\sigma$-phase is not observed after homogenization at $900{ }^{\circ} \mathrm{C}$, which is consistent with the diagram in Figure 4 [27].

\section{Phase Transformations in HEAs under the SPD Action}

It was found relatively recently that phase transformations can occur under the influence of SPD. This means that the phases in the sample after SPD will not be the same as they were before SPD [28-31]. For example, under the action of SPD, crystalline materials can transform into amorphous ones [32-42]. After SPD, they can contain one, two, or even several amorphous phases and vice versa, in amorphous materials under the influence of $\mathrm{SPD}$, the formation and growth of a crystalline phase can occur [43-59]. If the initial sample consists of two different solid solutions, then SPD almost always changes the concentration in these solid solutions [60-79]. For example, the concentration of element B in a solid solution based on element A can either increase or decrease. SPD is always accompanied by grain refinement and an increase in microhardness [80-92]. If various intermetallic compounds are present in the sample together with the solid solution, then under the influence of SPD, some intermetallic phases can be replaced by others [93-95]. Moreover, the disordering of ordered phases [96-106] can occur. Under the action of SPD, not only phase transformations associated with barrier mass transfer can occur but also martensitic phase transformations take place. During martensitic transformations, the nearest environment of atoms remains practically unchanged and there is no mass transfer over distances larger than interatomic [107-112].

The so-called effective temperature $T_{\text {eff }}$ can serve as a formal tool for describing such phase transformations [61-71]. Usually, one can find the phrases that appear in the sample after SPD in the equilibrium phase diagram at a certain temperature. Then, this state after SPD can be attributed to the value of this temperature called the effective temperature $T_{\text {eff }}$. Usually, the effective temperature $T_{\text {eff }}$ is higher than the temperature $T_{\mathrm{SPD}}$ at which the SPD treatment takes place. One can explain this fact with increased concentration of crystal structure defects (such as vacancies) arising upon SPD. The same thing happens 
when one heats the sample. Thus, the set of phases in the sample after SPD is similar to the set of phases after annealing at this increased effective temperature $T_{\text {eff. }}$. A significant difference, of course, is that high-temperature annealing usually leads to grain growth, while SPD leads to grain refinement [80-87]. In this section, we will show that phase transformations under the action of SPD can occur not only in binary or ternary systems but also in multicomponent HEAs.

In the modified Cantor alloy $\mathrm{Co}_{20} \mathrm{Cr}_{26} \mathrm{Fe}_{20} \mathrm{Mn}_{20} \mathrm{Ni}_{14}$, prepared by vacuum arc melting and annealed at $1050{ }^{\circ} \mathrm{C}$ for $24 \mathrm{~h} \mathrm{[26], \sigma -phase} \mathrm{precipitates} \mathrm{appear} \mathrm{in} \mathrm{the} \gamma$-matrix with fcc lattice. In the unmodified equiatomic Cantor alloy $\mathrm{Co}_{20} \mathrm{Cr}_{20} \mathrm{Fe}_{20} \mathrm{Mn}_{20} \mathrm{Ni}_{20}$, the $\sigma$-phase exists in the range from 450 to $800{ }^{\circ} \mathrm{C}$ (see Figure 4). HPT at room temperature, $5 \mathrm{GPa}$ and 1, 3, 5 plunger revolutions leads to the disappearance of the $\sigma$-phase. A singlephase fcc solid solution is formed again from the two-phase sample (see XRD patterns in Figure 5a [25]. Using the diagram in Figure 4 and the data in Figure 5a [25], we can assume that the effective temperature $T_{\text {eff }}$ of such a process exceeds $1050^{\circ} \mathrm{C}$, since above this temperature the $\sigma$-phase becomes unstable and only a single-phase fcc solid solution remains in equilibrium.
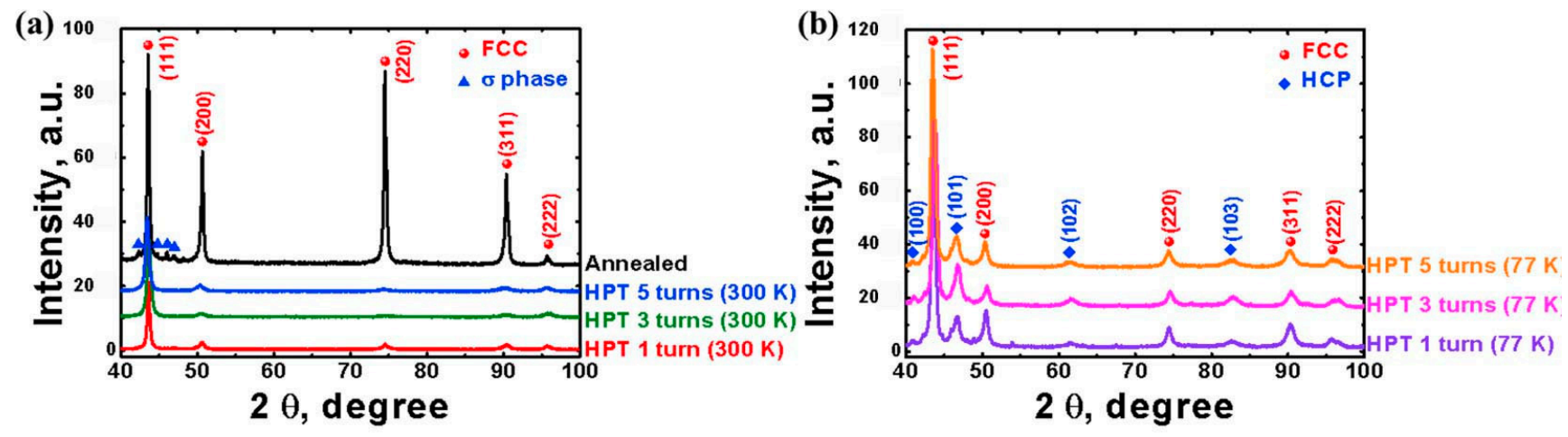

Figure 5. XRD patterns of the $\mathrm{CO}_{20} \mathrm{Cr}_{26} \mathrm{Fe}_{20} \mathrm{Mn}_{20} \mathrm{Ni}_{14}$ alloy in the annealed state and after $\mathrm{HPT}$ by 1,3 , and 5 anvil turns were conducted (a) at $300 \mathrm{~K}$ and (b) at $77 \mathrm{~K}$. The peak intensity is shown in arbitrary units. Reprinted with permission from Ref. [25]. Copyright 2017 Springer.

It is interesting that if HPT of the $\mathrm{Co}_{20} \mathrm{Cr}_{26} \mathrm{Fe}_{20} \mathrm{Mn}_{20} \mathrm{Ni}_{14}$ alloy annealed at $1050{ }^{\circ} \mathrm{C}$ is carried out at $77 \mathrm{~K}$, then the $\sigma$-phase also disappears (Figure $5 b$ ). In this case, the alloy does not remain single-phase with the fcc-lattice (as after HPT at room temperature, RT) but an additional phase with a hexagonal close-packed (hcp) lattice appears (Figure $5 b$ ). In the equiatomic Cantor alloy, $\varepsilon$-phase appears only upon annealing at a very high pressure of $14 \mathrm{GPa}$ [113]. A similar $\gamma \rightarrow \varepsilon$ phase transformation is observed, for example, in steels and is facilitated by the presence of twin GBs [114]. In the $\mathrm{Co}_{40} \mathrm{Cr}_{40} \mathrm{Fe}_{10} \mathrm{Mn}_{10}$ alloy, HPT causes the $\gamma \rightarrow \varepsilon$ phase transformation, and with strain increase, the fraction of the $\varepsilon$-phase increases as well (see Figure 6). Transmission electron microscopy (TEM) shows that the crystals of the $\gamma$ and $\varepsilon$ phases have the Shoji-Nishiyama (S-N) orientation relationship. This indicates the martensitic nature of the $\gamma \rightarrow \varepsilon$ transformation. Interestingly, with an increase in the HPT deformation, the ratio of the lattice constants c/a in the $\varepsilon$-phase does not change. It is close to the optimal c/a ratio required to fulfill the Shoji-Nishiyama $(\mathrm{S}-\mathrm{N})$ conditions. A similar martensitic transformation of the cubic $\beta$-phase with the bcc-lattice into the hexagonal $\omega$-phase is observed during HPT in many Ti- and Zr-based alloys $[109-111,115,116]$. For example, by changing the concentration of iron in titanium, it is possible to choose such a lattice constant of the $\beta$-phase that the necessary Nishiyama orientation relations will be fulfilled very accurately, and after HPT almost $95 \%$ of the $\beta$-phase is converted to the $\omega$-phase [111]. 


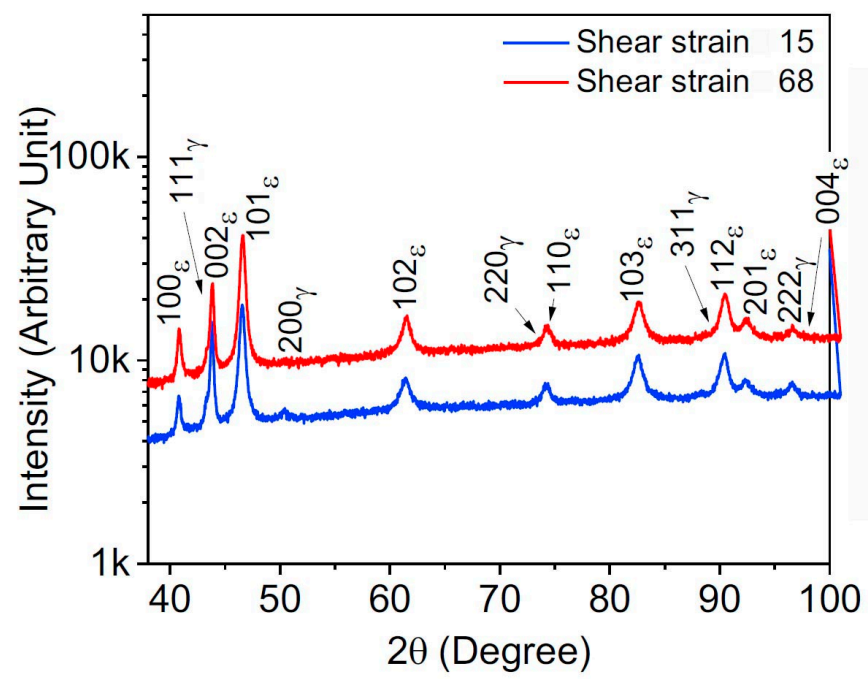

Figure 6. Indexed XRD pattern of HPT-processed specimens at shear strain 15 and 68 showing formation of a significant amount of hcp $\varepsilon$-phase. Reprinted with permission from Ref. [27]. Copyright 2021 Elsevier.

If HPT of the equiatomic Cantor alloy is carried out at a pressure of 5-6 GPa, then the initial fcc alloy remains single-phase with fcc structure [5,18-24]. If the pressure of HPT treatment is increased up to $10 \mathrm{GPa}$, then phase transformations occur in the initial fcc-alloy and not only the high-pressure $\varepsilon$-phase, but also the bcc-phase appears (see Figure 7). In this case, the portion of $\varepsilon$ - and bcc-phases in the sample increases not only with an increase in the number of revolutions from 0.25 to 5 but also with a decrease in the HPT temperature from RT to $77 \mathrm{~K}$ (Figure 7).

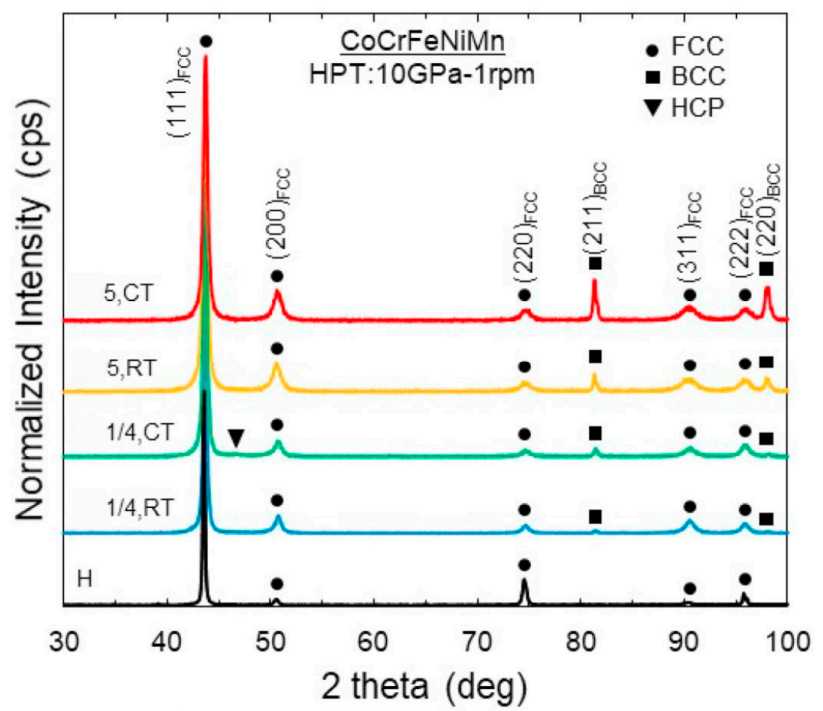

Figure 7. XRD patterns of the homogenized condition $(\mathrm{H})$ and near the edges of the disks processed by $\mathrm{N}=1 / 4$ and 5 turns HPT at RT and $77 \mathrm{~K}$ (CT). Reprinted with permission from Ref. [117]. Copyright 2021 Elsevier.

With equal channel angular pressing (ECAP), a different deformation scheme is implemented in comparison with HPT. Nevertheless, during ECAP of the Cantor alloy of equiatomic composition at a temperature of 300 or $900{ }^{\circ} \mathrm{C}$, a martensitic $\varepsilon$-phase is also formed [118]. Another option for SPD is multiaxial swaging. In [119], the Cantor alloy was subjected to a multiaxial swaging with $80 \%$ deformation in each pass. As a result, there was a complete amorphization of the alloy. This means that the crystal lattice was completely disordered due to the increased concentration of defects that do not have enough time to 
relax. Consequently, from the point of view of the effective temperature $T_{\text {eff }}$, this means that $T_{\text {eff }}$ exceeds the melting temperature of the Cantor alloy $\left(\sim 1350-1400{ }^{\circ} \mathrm{C}[120,121]\right)$.

In Ref. [122], the change in structure and properties under the influence of HPT was studied for the equiatomic alloy $\mathrm{AlCrFeCoNiNb}$. This alloy in the as-cast state consists of two phases, namely, a phase with a bcc lattice and a hexagonal Laves phase C14 with lattice constants $a=0.484 \mathrm{~nm}$ and $c=0.789 \mathrm{~nm}$. Their volume ratio is roughly 40:60. It is interesting that in the as-cast and in the as-homogenized state $\left(1000{ }^{\circ} \mathrm{C}, 1 \mathrm{~h}\right)$, the bcc-phase forms continuous interlayers along the GBs of the Laves phase (see Figure 8). This is due to the phenomena of GB wetting, which is frequently observed not only in binary alloys [122-125] but also in HEAs $[126,127]$. It is interesting to note that the structure with the distribution of the bcc phase along the GBs of the Laves phase is partially retained after HPT (see Figure 8). This behavior of the GB phase was observed also after HPT in magnesium alloys [128]. In this case, the grain size in each of the phases decreases to several hundred nanometers independently of each other.

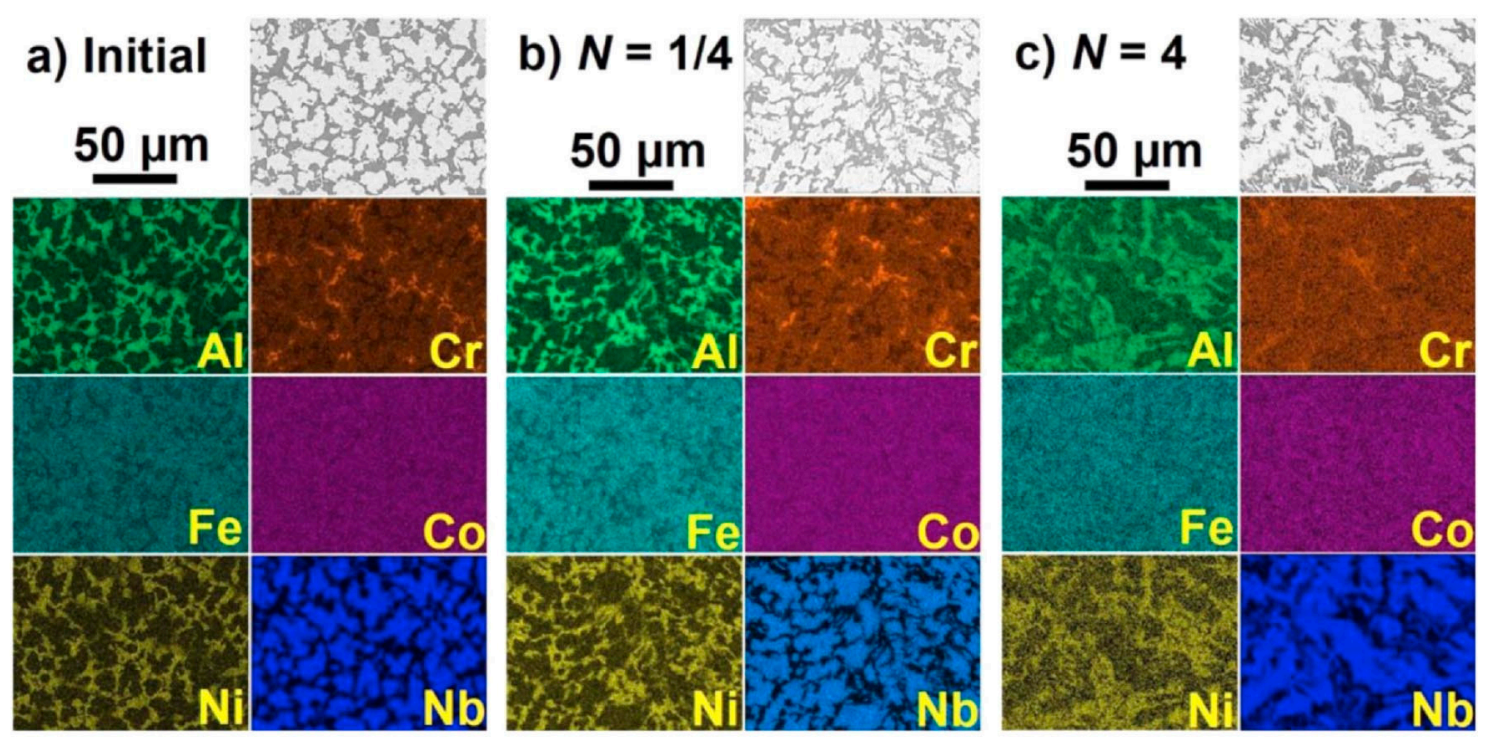

Figure 8. Scanning electron microscopy (SEM) micrographs (top) and corresponding electron dispersive X-ray (EDX) elemental mappings for (a) initial $\mathrm{AlCrFeCoNiNb}$ high-entropy alloy and for samples processed by HPT for (b) $1 / 4$ and (c) 4 turns. Reprinted with permission from Ref. [122]. Copyright 2021 Elsevier.

HPT of AlCrFeCoNiNb alloys at $6 \mathrm{GPa}$ and RT (0.25 and 4 plunger turns) leads to spinodal decomposition of the bcc phase [122]. During spinodal decomposition, regions enriched and depleted in chromium are formed. At the same time, they retain the bcc-lattice. The size of these regions is small, it is about $80 \mathrm{~nm}$. The decomposition of a solid solution caused by HPT has also been observed many times in binary systems such as Al-Zn and $\mathrm{Al}-\mathrm{Mg}[60,70,71], \mathrm{Cu}-\mathrm{Co}$ [61-64,74], Cu-Ag [65-68], Cu-Sn [68], Cu-Ni [75], Cu-In [76] and $\mathrm{Cu}-\mathrm{Cr}$ [78]. Comparison of the concentration in the solid solution after HPT with the equilibrium phase diagram allowed one to determine the effective temperature $T_{\text {eff }}$ for such HPT effect in binary alloys [68,74]. Moreover, we found that the effective temperature $T_{\text {eff }}$ increases proportionally with an increase in the activation energy for the diffusion of the second component in the matrix [74]. Unfortunately, in the case of HEA, the phase diagrams have not yet been sufficiently studied. This does not allow us to estimate the effective temperature in the case of spinodal decomposition, which was observed in [122]. However, a rough estimate of $T_{\text {eff }}$ is possible. Typically, spinodal decomposition is observed in binary systems at a temperature of about $50 \%$ of the melting point of the alloy. In our case, it will be approximately $700-800^{\circ} \mathrm{C}$.

In Ref. [129] the AlTiFeCoNi alloy with the addition of $0.45 \%$ carbon has been studied. In the as-cast state, this alloy contained large grains of an iron-rich ordered $\mathrm{L} 2{ }_{1}$ phase 
(about 77\%), surrounded by interlayers of an iron-depleted disordered bcc phase (about $22 \%$, with individual carbide inclusions with a fcc structure. Figure 9 shows the SEM micrographs and distribution of components in the as-cast state and after HPT (6 GPa for 5 turns, 1 rpm, RT).
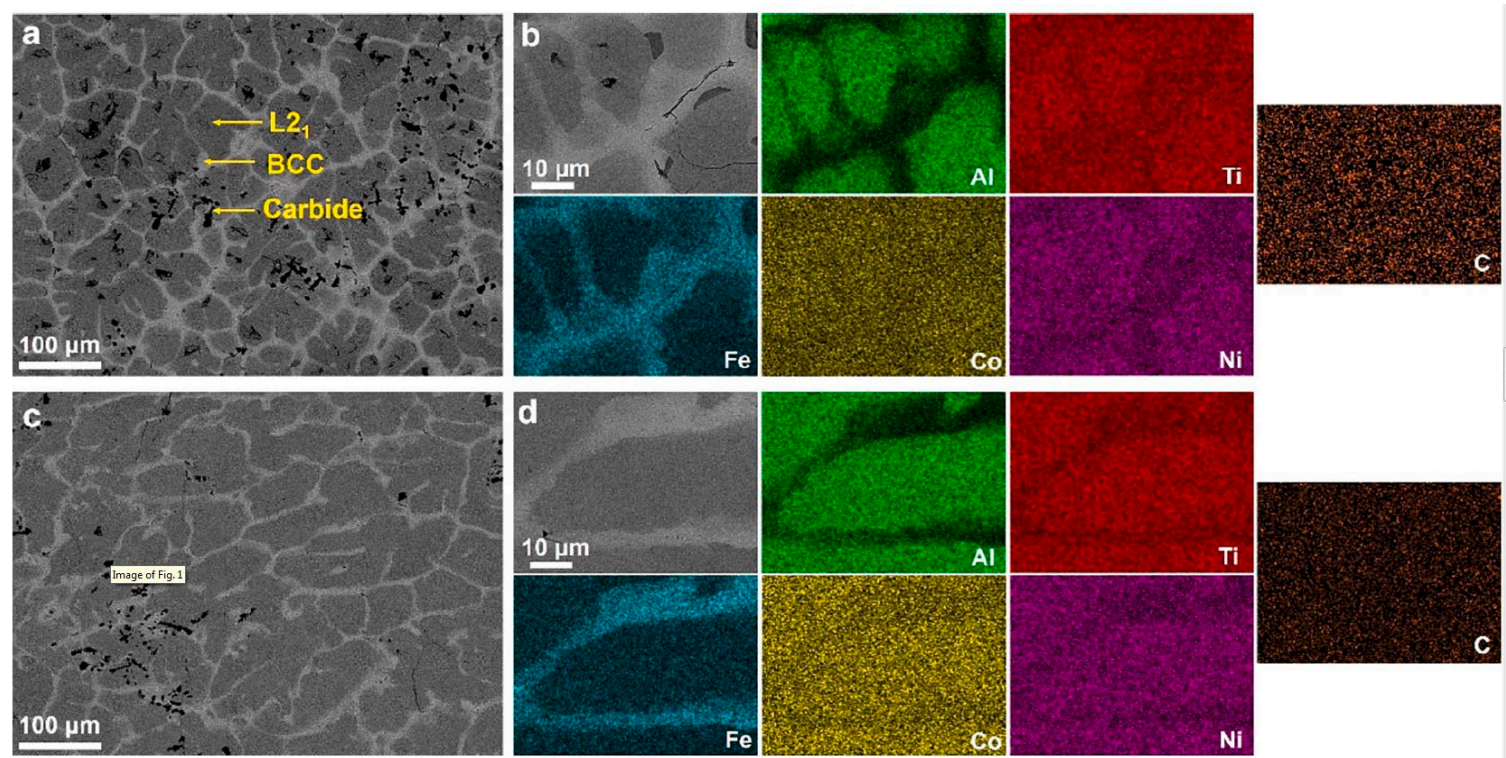

Figure 9. SEM micrographs and EDS mappings of AlTiFeCoNi-0.45\%C (a,b) before and $(\mathbf{c}, \mathbf{d})$ after HPT processing. Reprinted with permission from Ref. [129]. Copyright 2021 Elsevier.

It is clearly seen that, as in the previous case [122], the phenomenon of GB wetting is observed, namely, the grains of the matrix L2 1 phase are almost completely separated from each other by interlayers of a disordered bcc phase depleted in iron. A similar phenomenon of GB wetting by a melt or a second solid phase was observed in other works [126,127]. After HPT, such a structure of GB wetting, when the interlayers of the bcc phase separate the grains of the L2 1 phase from each other, almost did not change (see Figure 9). At the same time, as the results of XRD studies show (see Figure 10b), a phase transformation of the ordered phase $\mathrm{L}_{1}$ into the disordered bcc phase $\mathrm{B}_{2}$ took place. In [129], the thermodynamic calculations of the phase diagram were performed using the CALPHAD program (see Figure 10a). The results obtained show that the ordered L2 1 phase transforms into the disordered $\mathrm{B}_{2}$ phase at a temperature of about $400{ }^{\circ} \mathrm{C}$. This means that the disordering caused by HPT makes it possible to determine the effective temperature $T_{\text {eff }}$ of the HPT process as $T_{\text {eff }}=\sim 400{ }^{\circ} \mathrm{C}$.

(a)

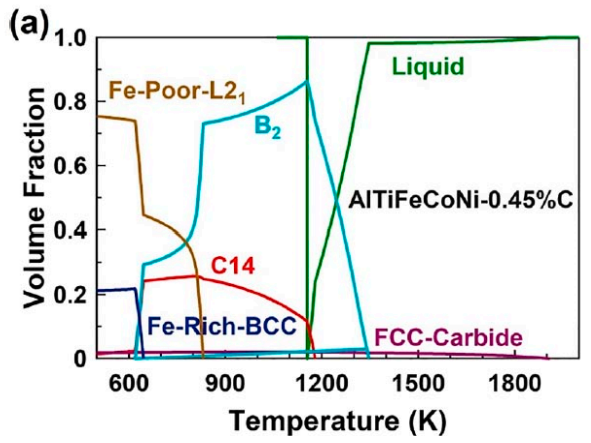

(b)

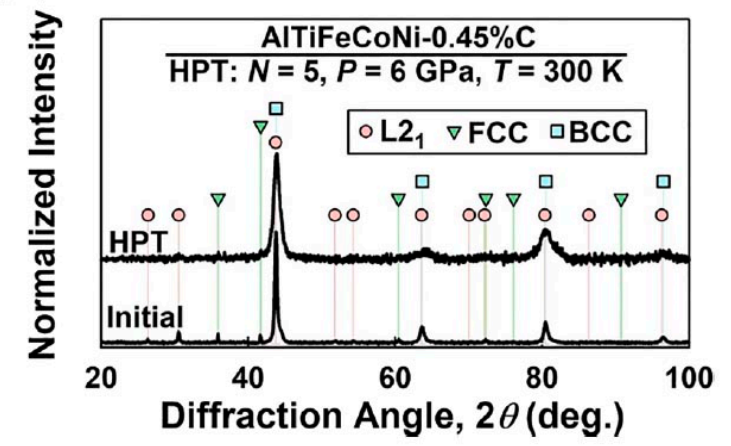

Figure 10. (a) Phase diagram calculated by CALPHAD program, and (b) XRD profiles of AlTiFeCoNi$0.45 \% \mathrm{C}$ before and after HPT processing. Reprinted with permission from Ref. [129]. Copyright 2021 Elsevier. 


\section{Equilibrium between the Composition of Bulk Phases and GB Segregation}

Any polycrystal consists of crystallites of bulk phases and GB or interphase boundaries (IBs) between them. It is well known that the composition of a thin (1-2 nm) layer at a GB or an IB significantly differs from the composition of the surrounding bulk phases. This phenomenon is called GB segregation. In equilibrium, there is a certain relationship between the composition of bulk phases and segregation at GBs and IBs. During SPD, significant refinement of grains usually occurs [80-87]. If the grain size before SPD can be tens, hundreds, or even thousands of micrometers, then after SPD the crystallite size drops to hundreds or tens of nanometers. Obviously, in this case, the specific area of GBs and IBs increases by several orders of magnitude. At the same time, at each new GB or IB, a segregation layer should form, the composition of which differs from that of the volume. If there are many such new interfaces, then the formation of respective segregation layers will require many atoms from bulk phases. The thickness of such segregation layers in HEAs after HPC can reach 5-10 nm [130]. In this case, the composition of the bulk phases can change significantly. These changes can become visible in XRD patterns since they should affect the lattice constant in a bulk solid solution. For example, it was observed that the composition of the solid solution in the bulk of copper-silver alloys or carbon steels significantly changes during HPT [131-135]. Segregation of the second component at GBs in nanocrystalline materials can lead to the fact that the total solubility of the second component in such a substance can be several times higher than the solubility of the second component in bulk [131-142].

An equiatomic five-component AlFeCoNiCu alloy was studied in [143]. After melting and casting it was homogenized at $1000{ }^{\circ} \mathrm{C}$ for $1 \mathrm{~h}$, and then subjected to HPT under $6 \mathrm{GPa}$, RT, $1 \mathrm{rpm}$, for various turns of $N=0$ (only compression), 1/16, 1/4, 1 and 4 . In the initial state, the alloy consisted of two phases, with fcc and bcc lattice. They were enriched and depleted in aluminum, respectively. At the beginning of the HPT process, with simple compression, as well as with $1 / 16$ turns, the $\mathrm{X}$-ray peaks remain in the same place. Then they begin to diverge in different directions. The peaks of the bcc-phase are shifted towards higher diffraction angles (this corresponds to a decrease in the lattice constant), and the peaks of the fcc-phase are shifted towards low diffraction angles (which corresponds to an increase in the lattice constant). As in all other cases, HPT led to a significant decrease in the grain size from tens of microns to tens of nanometers. In this case, the specific density of GBs increased, and segregation layers are formed on them due to the escape of atoms from the bulk to the GBs These layers are different in two different phases, bcc and $\mathrm{fcc}$, respectively. Therefore, their formation has a different effect on the concentration of atoms in the volume of these two phases. As a result, the lattice constant of the bcc-phase decreases, while the lattice constant of the fcc-phase increases.

In Ref. [144], the five-component equiatomic alloy HfNbTaTiZr in the as-cast state was subjected to HPT at 2.5 GB with a different number of plunger revolutions from 0 (simply with the application of pressure), and then a quarter turn, half a turn, one, 5 and 15 plunger turns. Both in the as-cast state and after HPT, the alloy consisted of one bcc phase. HPT resulted in grain refinement from about $200-500 \mu \mathrm{m}$ to $50 \mathrm{~nm}$. Figure 11 shows the XRD patterns for the as-cast sample and all samples subjected to HPT with a different number of revolutions. It is clearly seen that the peaks gradually broaden as the grains are refined and shift to the left, which corresponds to an increase in the lattice constant. Figure 12 shows the change in the lattice constant, the size of the coherent diffraction domains and the magnitude of microstrain with the number of plunger revolutions. As in the previous cases, such an increase in the lattice constant in the absence of phase transformations can only be explained by grain refinement, namely, by the formation of segregation layers at new GBs, which required the outflow of atoms from the bulk to the boundaries. 


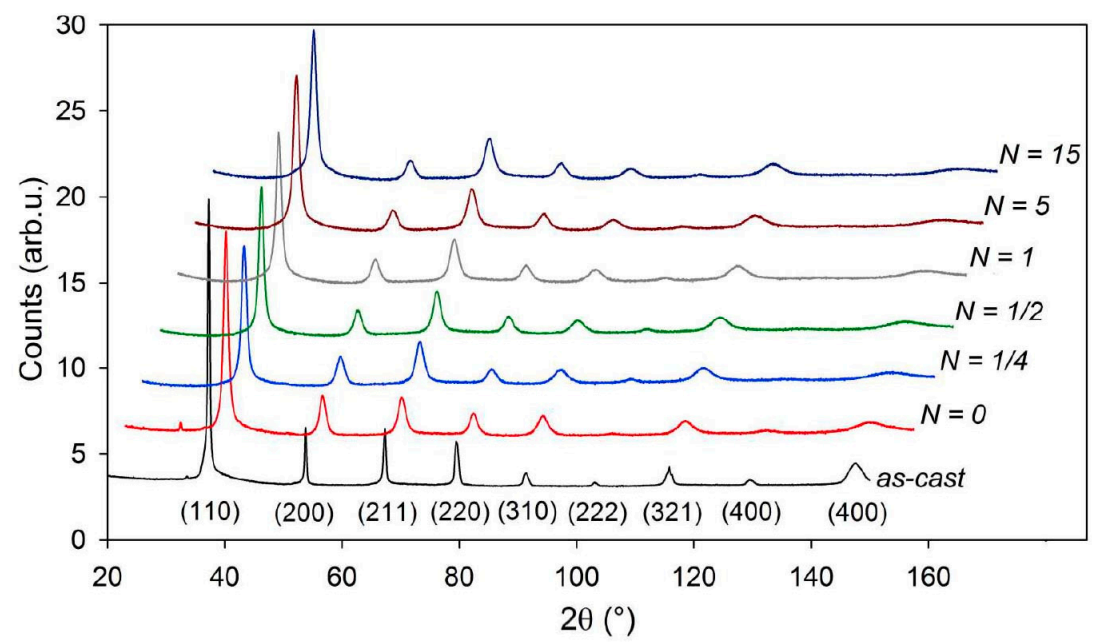

Figure 11. The development of XRD patterns for HfNbTaTiZr alloy during HPT straining for the various number of HPT revolutions N. Reprinted with permission from Ref. [144]. Copyright 2018 Elsevier.

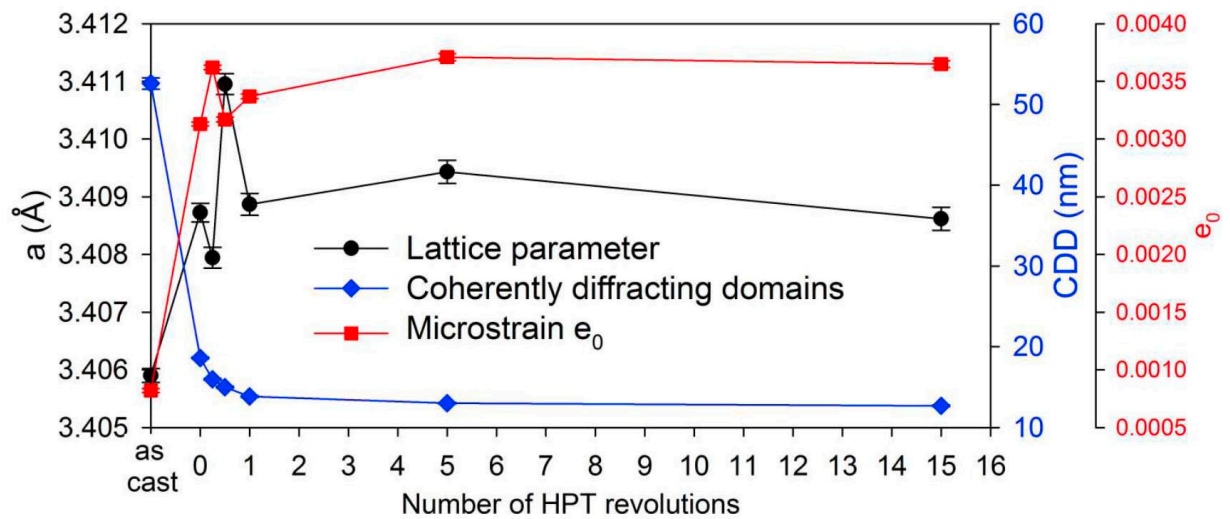

Figure 12. Results of the Rietveld refinement fit the HfNbTaTiZr alloy. The lattice constant $a$, the size of the coherent diffraction domains CDD and the magnitude of microstrain $e_{0}$ are shown in dependence on N. Reprinted with permission from Ref. [144]. Copyright 2018 Elsevier.

In Ref. [145], an equiatomic mixture of powders of cobalt, chromium, iron, nickel and manganese was taken as a starting material. This mixture was placed between the plungers of the HPT installation, compressed to a pressure of $5 \mathrm{GPa}$ and subjected to torsion with the number of revolutions reaching 100. The XRD patterns (Figure 13) show that after one revolution, the fcc solid solution phase is formed from the powder mixture, and after 10 revolutions the peaks of the bcc-phase completely disappear. The initial particle size was about $10 \mu \mathrm{m}$. The grain size in the homogeneous fcc-phase after one hundred revolutions was about $50 \mathrm{~nm}$. In Figure 13 it is clearly seen how the peaks for the fcc solid solution shift to the left with an increase in the number of revolutions. This shift corresponds to an increase in the fcc lattice constant. This effect, as in other studies considered above, can be explained by the formation of new GBs and the segregation of individual elements on them from the bulk solid solution. In addition, in [145], the microstructure of the samples was analyzed using atomic force tomography (APT). These high-resolution measurements showed, in particular, that the GBs in the solid solution after HPT are markedly enriched in manganese. 


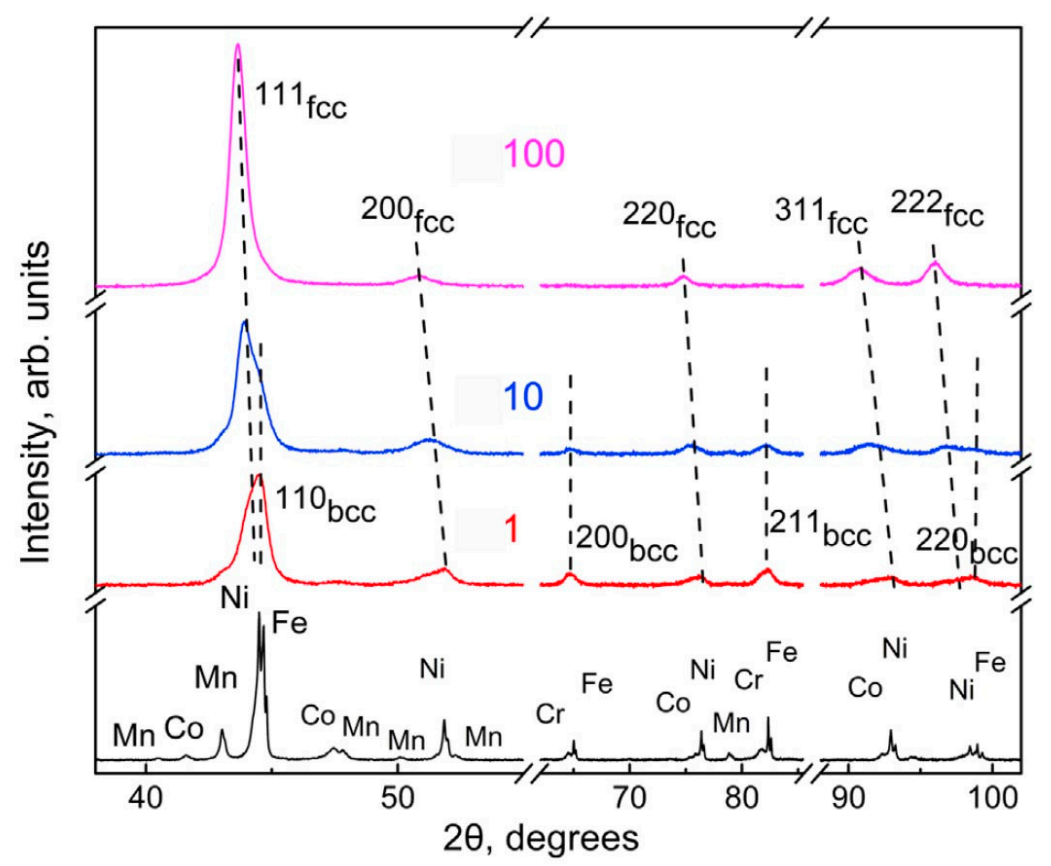

Figure 13. XRD patterns of "as-mixed" multicomponent powder (bottom curve) and CoCrFeNiMn alloys after HPT for $n=1,10$ and 100 rotations (from lower to upper curves). Tilted dashed lines indicate the changes of peak positions for fcc solid solution. Reprinted with permission from Ref. [145]. Copyright 2019 Elsevier.

In Ref. [146], a three-component iron-cobalt-nickel alloy was subjected to HPT. Both before and after HPT, the alloy consisted of one fcc phase. After HPT, the grain size was approximately $50 \mathrm{~nm}$. Then a series of samples of this alloy was annealed at temperatures of $600-800{ }^{\circ} \mathrm{C}$. The alloy remained single-phase, but the grain size increased at the same time by about $5-10 \mu \mathrm{m}$. The XRD patterns shown in Figure 14 demonstrate that although the alloy remains single-phase with the fcc structure, the lattice constant changes. Peaks being wide after HPT become narrow (due to grain growth) and noticeably shift to the right. This corresponds to a decrease in the lattice constant in volume. This phenomenon can be explained by the fact that with an increase in the grain size by two and a half orders of magnitude, the specific area of GBs drops sharply and the atoms that formed segregation layers at the boundaries are released and passed into the volume. In this case, the lattice constant changes noticeably.

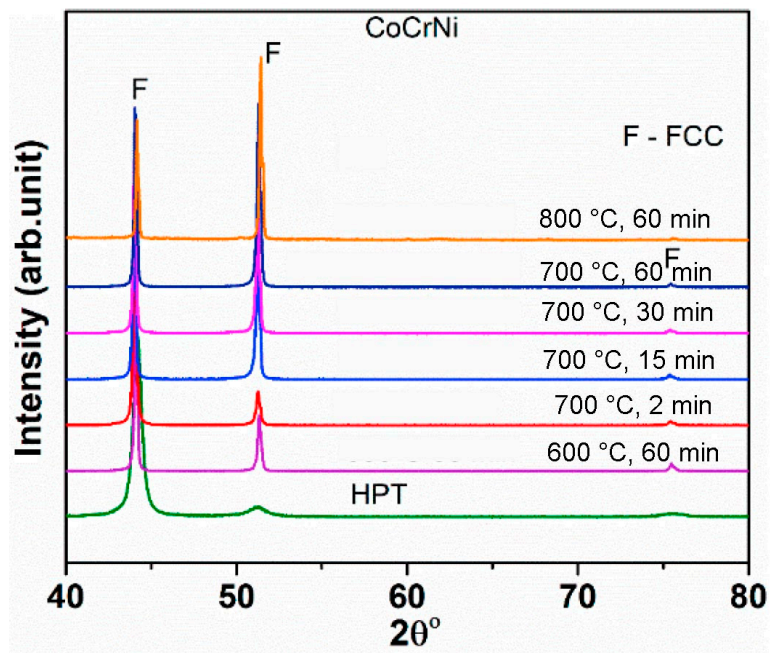

Figure 14. XRD patterns of CoCrNi alloy in different processing conditions illustrating the presence of a single fcc phase. Reprinted with permission from Ref. [146]. Copyright 2018 MDPI. 
So far, in our reasoning, we have not taken into account individual differences between GBs. Meanwhile, the GB structure and properties substantially depend on their misorientation angles and the orientation of the GB plane [147-149]. There is ample evidence that HEAs also contain different types of GBs. In particular, many of them can contain a large number of deformation and annealing twins [150-152]. On the other hand, it is well known that twin GBs differ greatly in structure, composition and properties from general GBs and other coincidence GBs [153-155]. For example, the number and morphology of twins in HEAs strongly depend both on the composition of these alloys and on their pretreatment [23,156-158]. In addition, the faceting-roughening GB phase transitions lead to the fact that the spectrum of GB properties also depends on temperature, as well as on the composition of the alloy $[159,160]$. Thus, we demonstrated that SPD can significantly expand the spectrum of the structure and properties of HEAs, and the simultaneous use of the features of phase transformations gives material scientists and engineers an important tool for purposefully changing the properties of WESs [161-170].

The area of HEAs is very broad; however, this review appears quite short. Nevertheless, we really discussed or mentioned here all papers from the intersection of areas "HEAs", "SPD" and "phase transformations". It is because the combination of these approaches is quite new and concerns mainly the Cantor alloy and similar HEAs. The goal of this review is to demonstrate how fruitful can be the application of ideas of bulk and GB phase transitions and SPD to various HEAs. Therefore, we can expect the new breakthrough results in similar investigations, for example for novel HEAs obtained by the additive manufacturing (like AlCoFeNiTiV $0.9 \mathrm{Sm}_{0.1}$ and $\mathrm{AlCoFeNiV}_{0.9} \mathrm{Sm}_{0.1} \mathrm{HEAs}$ with high corrosion resistance [171], hybrid HEAs based on AlCoFeNiSmTiVZr system [172], as well as titanium-free AlCoCrFeNiMn, $\mathrm{CoCr}_{1.3} \mathrm{FeMnNi}_{0.7}, \mathrm{AlCoCrFeNi}_{1.3}$, and $\mathrm{AlCoCr}_{1.3} \mathrm{FeNi}_{1.3}$ HEAs [173]). Even more promising can be the studies of high-entropy oxides and other ceramics [174,175].

\section{Conclusions}

We have shown that SPD makes it possible to determine the borders of single-phase regions of the existence of a multicomponent solid solution in HEAs. The GBs that are formed in $\mathrm{t} \mathrm{HEAs} \mathrm{during} \mathrm{SPD} \mathrm{serve} \mathrm{as} \mathrm{pathways} \mathrm{for} \mathrm{accelerated} \mathrm{diffusion,} \mathrm{and} \mathrm{during} \mathrm{the}$ annealing of such samples, the precipitates of the second phase are rapidly formed. Such accelerated mass transfer makes it possible to accurately determine the border temperature for the single-phase solid solution area in the multicomponent phase diagram of HEAs. In addition, SPD causes a variety of phase transformations in HEAs. These include the decomposition of a single-phase solid solution with the formation of second-phase particles, the formation of high-pressure phases, amorphization, and spinodal decomposition. As we have already noted, during SPD, a large number of new GB are formed due to grain refinement. These new GBs have segregation layers, the composition of which differs from the composition of the bulk solid solution. For the formation of segregation layers at new GBs, atoms from the bulk are required. As a result, the composition of the solid solution in the volume changes during SPD. All these SPD processes make it possible to adapt the composition, structure and useful properties of HEA to solve a wide range of problems in various fields of industry, science and health care. In particular, the possibility of modifying individual properties of HEA (especially those with titanium, zirconium and hafnium), which have already proven their safety and reliability during a long history of use in clinical practice, can significantly diversify the range of medical devices developed on their basis, expanding the scope of their application in medicine.

Author Contributions: Conceptualization, R.K., M.V.K. and L.K.; methodology, R.K., M.V.K. and P.B.S.; formal analysis, N.Y.A., M.V.K. and P.B.S.; writing-original draft preparation, B.B.S., N.Y.A. and L.K.; writing-review and editing, B.B.S. and L.K.; supervision, R.Z.V. and L.K.; project administration, R.Z.V., B.B., O.A.K. and R.K.; funding acquisition, B.B.S., B.B., O.A.K. and R.K. All authors have read and agreed to the published version of the manuscript. 
Funding: This research was funded by the Russian Ministry of Science and Higher Education (contract no. 075-15-2021-999 grant no. 13.2251.21.0058).

Institutional Review Board Statement: Not applicable.

Informed Consent Statement: Not applicable.

Data Availability Statement: All the data required to reproduce these experiments are present in the article.

Acknowledgments: We acknowledge the support by the KIT-Publication Fund of the Karlsruhe Institute of Technology. Support from the The Volkswagen Foundation through the Cooperation Project Az.:97 751 is also acknowledged.

Conflicts of Interest: The authors declare no conflict of interest.

\section{References}

1. Cantor, B.; Chang, I.T.H.; Knight, P.; Vincent, A.J.B. Microstructural development in equiatomic multicomponent alloys. Mater. Sci. Eng. A 2004, 375-377, 213-218. [CrossRef]

2. Yeh, J.W.; Chen, S.K.; Lin, S.J.; Gan, J.Y.; Chin, T.S.; Shun, T.T.; Tsau, C.H.; Chang, S.Y. Nanostructured high-entropy alloys with multiple principal elements: Novel alloy design concepts and outcomes. Adv. Eng. Mater. 2004, 6, 299-303. [CrossRef]

3. Senkov, O.N.; Wilks, G.B.; Miracle, D.B.; Chuang, C.P.; Liaw, P.K. Refractory high-entropy alloys. Intermetallics 2010, 18, 1758-1765. [CrossRef]

4. Senkov, O.N.; Isheim, D.; Seidman, D.N.; Pilchak, A.L. Development of a refractory high entropy superalloy. Entropy 2016, 18, 102. [CrossRef]

5. Otto, F.; Dlouhý, A.; Pradeep, K.G.; Kubénová, M.; Raabe, D.; Eggeler, G.; George, E.P. Decomposition of the single-phase high-entropy alloy CrMnFeCoNi after prolonged anneals at intermediate temperatures. Acta Mater. 2016, 112, 40-52. [CrossRef]

6. Bryła, K.; Morgiel, J.; Faryna, M.; Edalati, K.; Horita, Z. Effect of high-pressure torsion on grain refinement, strength enhancement and uniform ductility of EZ magnesium alloy. Mater. Lett. 2018, 212, 323-326. [CrossRef]

7. Edalati, K.; Hashiguchi, Y.; Pereirac, P.H.R.; Horita, Z.; Langdon, T.G. Effect of temperature rise on microstructural evolution during high-pressure torsion. Mater. Sci. Eng. A 2018, 714, 167-171. [CrossRef]

8. Mazilkin, A.A.; Kogtenkova, O.A.; Straumal, B.B.; Valiev, R.Z.; Baretzky, B. Formation of nanostructure during high-pressure torsion of Al-Zn, Al-Mg and Al-Zn-Mg alloys. Def. Diff. Forum 2005, 237-240, 739-744. [CrossRef]

9. Mazilkin, A.A.; Baretzky, B.; Enders, S.; Kogtenkova, O.A.; Straumal, B.B.; Rabkin, E.I.; Valiev, R.Z. Hardness of nanostructured $\mathrm{Al}-\mathrm{Zn}, \mathrm{Al}-\mathrm{Mg}$ and Al-Zn-Mg alloys obtained by high-pressure torsion. Def. Diff. Forum 2006, 249, 155-160. [CrossRef]

10. Kulagin, R.; Beygelzimer, Y.; Ivanisenko, Y.; Mazilkin, A.; Straumal, B.; Hahn, H. Instabilities of interfaces between dissimilar metals induced by high pressure torsion. Mater. Lett. 2018, 222, 172-175. [CrossRef]

11. Valiev, R.Z.; Islamgaliev, R.K.; Alexandrov, I.V. Bulk nanostructured materials from severe plastic deformation. Progr. Mater. Sci. 2000, 45, 103-189. [CrossRef]

12. Bryła, K.; Krystian, M.; Horky, J.; Mingler, B.; Mroczka, K.; Kurtyka, P.; Lityńska-Dobrzyńska, L. Improvement of strength and ductility of an EZ magnesium alloy by applying two different ECAP concepts to processable initial states. Mater. Sci. Eng. A 2018, 737, 318-327. [CrossRef]

13. Lukyanova, E.A.; Martynenko, N.S.; Serebryany, V.N.; Belyakov, A.N.; Rokhlin, L.L.; Dobatkin, S.V.; Estrin, Y.Z. Structure and mechanical and corrosion properties of a magnesium $\mathrm{Mg}-\mathrm{Y}-\mathrm{Nd}-\mathrm{Zr}$ alloy after high pressure torsion. Russ. Metall. 2017, 2017, 912-921. [CrossRef]

14. Krala, P.; Dvorak, J.; Sklenicka, V.; Masuda, T.; Horita, Z.; Kucharova, K.; Kvapilova, M.; Svobodova, M. Microstructure and creep behaviour of P92 steel after HPT. Mater. Sci. Eng. A 2018, 723, 287-295. [CrossRef]

15. Sabbaghianrad, S.; Torbati-Sarraf, S.A.; Langdon, T.G. An investigation of the limits of grain refinement after processing by a combination of severe plastic deformation techniques: A comparison of $\mathrm{Al}$ and Mg alloys. Mater. Sci. Eng. A 2018, 712, 373-379. [CrossRef]

16. Tirsatine, K.; Azzeddine, H.; Huang, Y.; Baudin, T.; Helbert, A.-L.; Brisset, F.; Bradai, D.; Langdon, T.G. An EBSD analysis of Fe-36\%Ni alloy processed by HPT at ambient and a warm temperature. J. Alloys Compd. 2018, 753, 46-53. [CrossRef]

17. Wu, Y.; Liaw, P.K.; Zhang, Y. Preparation of bulk TiZrNbMoV and NbTiAlTaV high-entropy alloys by powder sintering. Metals 2021, 11, 1748. [CrossRef]

18. Shahmir, H.; Nili-Ahmadabadi, M.; Shafiee, A.; Langdon, T.G. Effect of a minor titanium addition on the superplastic properties of a CoCrFeNiMn high-entropy alloy processed by high-pressure torsion. Mater. Sci. Eng. A 2018, 718, 468-476. [CrossRef]

19. Shahmir, H.; Nili-Ahmadabadi, M.; Shafiee, A.; Andrzejczuk, M.; Lewandowska, M.; Langdon, T.G. Effect of Ti on phase stability and strengthening mechanisms of a nanocrystalline CoCrFeMnNi high-entropy alloy. Mater. Sci. Eng. A 2018, 725, 196-206. [CrossRef]

20. Shahmir, H.; He, J.; Lu, Z.; Kawasaki, M.; Langdon, T.G. Effect of annealing on mechanical properties of a nanocrystalline CoCrFeNiMn high-entropy alloy processed by high-pressure torsion. Mater. Sci. Eng. A 2016, 676, 294-303. [CrossRef] 
21. Shahmir, H.; Mousavi, T.; He, J.; Lu, Z.; Kawasaki, M.; Langdon, T.G. Microstructure and properties of a CoCrFeNiMn highentropy alloy processed by equal-channel angular pressing. Mater. Sci. Eng. A 2017, 705, 411-419. [CrossRef]

22. Reddy, T.S.; Wani, I.S.; Bhattacharjee, T.; Reddy, S.R.; Saha, R.; Bhattacharjee, P.P. Severe plastic deformation driven nanostructure and phase evolution in a $\mathrm{Al}_{0.5} \mathrm{CoCrFeMnNi}$ dual phase high entropy alloy. Intermetallics 2017, 91, 150-157. [CrossRef]

23. Schuh, B.; Mendez-Martin, F.; Völker, B.; George, E.P.; Clemens, H.; Pippan, R.; Hohenwarter, A. Mechanical properties, microstructure and thermal stability of a nanocrystalline CoCrFeMnNi high-entropy alloy after severe plastic deformation. Acta Mater. 2015, 96, 258-268. [CrossRef]

24. You, D.; Yang, G.; Cho, Y.-H.; Kim, J.-K. Crack-resistant $\sigma / \mathrm{FCC}$ interfaces in the $\mathrm{Fe}_{40} \mathrm{Mn}_{40} \mathrm{Co}_{10} \mathrm{Cr}_{10}$ high entropy alloy with the dispersed $\sigma$-phase. Mater. Sci. Eng. A 2022, 831, 142039. [CrossRef]

25. Moon, J.; Qi, Y.; Tabachnikova, E.; Estrin, Y.; Choi, W.-M.; Joo, S.-H.; Lee, B.-J.; Podolskiy, A.; Tikhonovsky, M.; Kim, H.S. Microstructure and mechanical properties of high-entropy alloy $\mathrm{Co}_{20} \mathrm{Cr}_{26} \mathrm{Fe}_{20} \mathrm{Mn}_{20} \mathrm{Ni}_{14}$ processed by high-pressure torsion at $77 \mathrm{~K}$ and $300 \mathrm{~K}$. Sci. Rep. 2018, 8, 11074. [CrossRef]

26. Moon, J.; Qi, Y.; Tabachnikova, E.; Estrin, Y.; Choi, W.-M.; Joo, S.-H.; Lee, B.-J.; Podolskiy, A.; Tikhonovsky, M.; Kim, H.S. Deformation-induced phase transformation of $\mathrm{Co}_{20} \mathrm{Cr}_{26} \mathrm{Fe}_{20} \mathrm{Mn}_{20} \mathrm{Ni}_{14}$ high-entropy alloy during high-pressure torsion at $77 \mathrm{~K}$. Mater. Lett. 2017, 202, 86-88. [CrossRef]

27. Chandan, A.K.; Hung, P.T.; Kishore, K.; Kawasaki, M.; Chakraborty, J.; Gubicza, J. On prominent TRIP effect and non-basal slip in a TWIP high entropy alloy during high-pressure torsion processing. Mater. Charact. 2021, 178, 111284. [CrossRef]

28. Sauvage, X.; Chbihi, A.; Quelennec, X. Severe plastic deformation and phase transformations. J. Phys. 2010, 240, 012003. [CrossRef]

29. Straumal, B.B.; Kilmametov, A.R.; Mazilkin, A.A.; Gornakova, A.S.; Fabrichnaya, O.B.; Kriegel, M.J.; Rafaja, D.; Bulatov, M.F.; Nekrasov, A.N.; Baretzky, B. The formation of the $\omega$ phase in the titanium-iron system under shear deformation. JETP Lett. 2020, 111, 568-574. [CrossRef]

30. Teitel', E.I.; Metlov, L.S.; Gunderov, D.V.; Korznikov, A.V. On the structural and phase transformations in solids induced by severe plastic deformation. Phys. Metall. Metallogr. 2012, 113, 1162-1168. [CrossRef]

31. Razumov, I.K.; Ermakov, A.Y.; Gornostyrev, Y.N.; Straumal, B.B. Nonequilibrium phase transformations in alloys subjected to severe plastic deformation. Phyz. Usp. 2020, 63, 733-757. [CrossRef]

32. Sergueeva, A.V.; Song, C.; Valiev, R.Z.; Mukherjee, A.K. Structure and properties of amorphous and nanocrystalline NiTi prepared by severe plastic deformation and annealing. Mater. Sci. Eng. A 2003, 339, 159-165. [CrossRef]

33. Prokoshkin, S.D.; Khmelevskaya, I.Y.; Dobatkin, S.V.; Trubitsyna, I.B.; Tatyanin, E.V.; Stolyarov, V.V.; Prokofiev, E.A. Alloy composition, deformation temperature, pressure and post-deformation annealing effects in severely deformed Ti-Ni based shape memory alloys. Acta Mater. 2005, 53, 2703-2714. [CrossRef]

34. Sauvage, X.; Renaud, L.; Deconihout, B.; Blavette, D.; Ping, D.H.; Hono, K. Solid state amorphization in cold drawn Cu/Nb wires. Acta. Mater. 2001, 49, 389-394. [CrossRef]

35. Miyazaki, T.; Terada, D.; Miyajima, Y.; Suryanarayana, C.; Murao, R.; Yokoyama, Y.; Sugiyama, K.; Umemoto, M.; Todaka, T.; Tsuji, N. Synthesis of non-equilibrium phases in immiscible metals mechanically mixed by high pressure torsion. J. Mater. Sci. 2011, 46, 4296-4301. [CrossRef]

36. Mazilkin, A.A.; Abrosimova, G.E.; Protasova, S.G.; Straumal, B.B.; Schütz, G.; Dobatkin, S.V.; Bakai, A.S. Transmission electron microscopy investigation of boundaries between amorphous "grains" in $\mathrm{Ni}_{50} \mathrm{Nb}_{20} \mathrm{Y}_{30}$ alloy. J. Mater. Sci. 2011, 46, 4336-4342. [CrossRef]

37. Stolyarov, V.V.; Gunderov, D.V.; Popov, A.G.; Gaviko, V.S.; Ermolenko, A.S. Structure evolution and changes in magnetic properties of severe plastic deformed $\mathrm{Nd}(\mathrm{Pr})-\mathrm{Fe}-\mathrm{B}$ alloys during annealing. J. Alloys Compd. 1998, 281, 69-71. [CrossRef]

38. Edalati, K.; Yokoyama, Y.; Horita, Z. High-pressure torsion of machining chips and bulk discs of amorphous $\mathrm{Zr}_{50} \mathrm{Cu}_{30} \mathrm{Al}_{10} \mathrm{Ni}_{10}$. Mater. Trans. 2010, 51, 23-26. [CrossRef]

39. Straumal, B.B.; Mazilkin, A.A.; Protasova, S.G.; Goll, D.; Baretzky, B.; Bakai, A.S.; Dobatkin, S.V. Formation of two amorphous phases in the $\mathrm{Ni}_{60} \mathrm{Nb}_{18} \mathrm{Y}_{22}$ alloy after high pressure torsion. Kovove Mater. Metall. Mater. 2011, 49, 17-22. [CrossRef]

40. Révész, Á.; Hóbor, S.; Lábár, J.L.; Zhilyaev, A.P.; Kovácz, Z. Partial amorphization of a Cu-Zr-Ti alloy by high pressure torsion. J. Appl. Phys. 2006, 100, 103522. [CrossRef]

41. Straumal, B.B.; Kilmametov, A.R.; Mazilkin, A.A.; Protasova, S.G.; Kolesnikova, K.I.; Straumal, P.B.; Baretzky, B. Amorphization of Nd-Fe-B alloy under the action of high-pressure torsion. Mater. Lett. 2015, 145, 63-66. [CrossRef]

42. Straumal, B.B.; Mazilkin, A.A.; Protasova, S.G.; Gunderov, D.V.; López, G.A.; Baretzky, B. Amorphization of crystalline phases in the Nd-Fe-B alloy driven by the high-pressure torsion. Mater. Lett. 2015, 161, 735-739. [CrossRef]

43. Boucharat, N.; Hebert, R.; Rösner, H.; Valiev, R.; Wilde, G. Nanocrystallization of amorphous $\mathrm{Al}_{88} \mathrm{Y}_{7} \mathrm{Fe}_{5}$ alloy induced by plastic deformation. Scr. Mater. 2005, 53, 823-828. [CrossRef]

44. Henits, P.; Révész, Á.; Zhilyaev, A.P.; Kovács, Z. Severe plastic deformation induced nanocrystallization of melt-spun $\mathrm{Al}_{85} \mathrm{Y}_{8} \mathrm{Ni}_{5} \mathrm{Co}_{2}$ amorphous alloy. J. Alloys Compd. 2008, 461, 195-199. [CrossRef]

45. Pershina, E.; Abrosimova, G.; Aronin, A.; Matveev, D.; Tkatch, V. Crystallization features in $\mathrm{Al}_{90} \mathrm{Y}_{10}$ amorphous alloy under a various external influence. Mater. Lett. 2014, 134, 60-63. [CrossRef]

46. Pershina, E.; Matveev, D.; Abrosimova, G.; Aronin, A. Formation of nanocrystals in an amorphous $\mathrm{Al}_{90} \mathrm{Y}_{10}$ alloy. Mater. Charact. 2017, 133, 87-93. [CrossRef] 
47. Kovács, Z.; Henits, P.; Zhilyaev, A.P.; Révész, Á. Deformation induced primary crystallization in a thermally non-primary crystallizing amorphous $\mathrm{Al}_{85} \mathrm{Ce}_{8} \mathrm{Ni}_{5} \mathrm{Co}_{2}$ alloy. Scr. Mater. 2006, 54, 1733-1737. [CrossRef]

48. Henits, P.; Révész, Á.; Varga, L.K.; Kovács, Z. The evolution of the microstructure in amorphous $\mathrm{Al}_{85} \mathrm{Ce}_{8} \mathrm{Ni}_{5} \mathrm{Co}_{2}$ alloy during heat treatment and severe plastic deformation: A comparative study. Intermetallics 2011, 19, 267-275. [CrossRef]

49. Abrosimova, G.; Aronin, A.; Matveev, D.; Pershina, E. Nanocrystal formation, structure and magnetic properties of Fe-Si-B amorphous alloy after deformation. Mater. Lett. 2013, 97, 15-17. [CrossRef]

50. Li, W.; Li, L.; Nan, Y.; Xu, Z.; Zhang, X.; Popov, A.G.; Gunderov, D.V.; Stolyarov, V.V. Nanocrystallization and magnetic properties of amorphous $\mathrm{Nd}_{9} \mathrm{Fe}_{85} \mathrm{~B}_{6}$ subjected to high-pressure torsion deformation upon annealing. J. Appl. Phys. 2008, 104, 023912. [CrossRef]

51. Li, W.; Li, X.; Guo, D.; Sato, K.; Gunderov, D.V.; Stolyarov, V.V.; Zhang, X. Atomic-scale structural evolution in amorphous $\mathrm{Nd}_{9} \mathrm{Fe}_{85} \mathrm{~B}_{6}$ subjected to severe plastic deformation at room temperature. Appl. Phys. Lett. 2009, 94, 231904. [CrossRef]

52. Ubyivovk, E.V.; Boltynjuk, E.V.; Gunderov, D.V.; Churakova, A.A.; Kilmametov, A.R.; Valiev, R.Z. HPT-induced shear banding and nanoclustering in a TiNiCu amorphous alloy. Mater. Lett. 2017, 209, 327-329. [CrossRef]

53. Gunderov, D.V.; Boltynjuk, E.V.; Ubyivovk, E.V.; Lukyanov, A.V.; Churakova, A.A.; Kilmametov, A.R.; Zamula, Y.S.; Valiev, R.Z. Cluster structure in amorphous Ti-Ni-Cu alloys subjected to highpressure torsion deformation. J. Alloys Compd. 2018, 749, 612-619. [CrossRef]

54. Kovács, Z.; Schafler, E.; Kovács Kisc, V.; Szommer, P.J.; Révész, Á. High pressure torsion of a Vitreloy bulk metallic glass near the glass transition temperature. J. Non Cryst. Solids 2018, 498, 25-31. [CrossRef]

55. Yamada, M.; Kamisato, R.; Yamasaki, T.; Adachi, H.; Tsuchiya, K.; Yokoyama, Y. Nanocrystallization of Zr-Cu-Ni-Al-Au glassy alloys during severe plastic deformation. IOP Conf. Ser. Mater. Sci. Eng. 2014, 63, 012167. [CrossRef]

56. Vierke, J.; Schumacher, G.; Pilyugin, V.P.; Denks, I.A.; Zizak, I.; Wolf, C.; Wanderka, N.; Wollgarten, M.; Banhart, J. Deformationinduced crystallization in amorphous $\mathrm{Al}_{85} \mathrm{Ni}_{10} \mathrm{La}_{5}$ alloy. J. Alloys Compd. 2010, 493, 683-691. [CrossRef]

57. Permyakova, I.; Glezer, A. Amorphous-nanocrystalline composites prepared by high-pressure torsion. Metals 2020, 10, 511. [CrossRef]

58. Pushin, V.G.; Kuranova, N.N.; Pushin, A.V.; Valiev, R.Z.; Kourov, N.I.; Teplykh, A.E.; Uksusnikov, A.N. Formation of nanocrystalline structure in the amorphous $\mathrm{Ti}_{50} \mathrm{Ni}_{25} \mathrm{Cu}_{25}$ alloy upon severe thermomechanical treatment and the size effect of the thermoelastic martensitic B2-B19 transformation. Phys. Met. Metallogr. 2012, 113, 271-282. [CrossRef]

59. Pushin, V.G.; Kuranova, N.N.; Pushin, A.V.; Kourov, N.I.; Pilyugin, V.P. Formation of the nanocrystalline structure in the $\mathrm{Ti}_{50} \mathrm{Ni}_{25} \mathrm{Cu}_{25}$ shape memory alloy under severe thermomechanical treatment. Phys. Met. Metallogr. 2011, 112, 603-612. [CrossRef]

60. Mazilkin, A.A.; Straumal, B.B.; Rabkin, E.; Baretzky, B.; Enders, S.; Protasova, S.G.; Kogtenkova, O.A.; Valiev, R.Z. Softening of nanostructured Al-Zn and Al-Mg alloys after severe plastic deformation. Acta Mater. 2006, 54, 3933-3939. [CrossRef]

61. Straumal, B.; Kilmametov, A.R.; Kucheev, Y.O.; Kurmanaeva, L.; Ivanisenko, Y.; Baretzky, B.; Korneva, A.; Zięba, P.; Molodov, D.A. Phase transitions during high pressure torsion of $\mathrm{Cu}-\mathrm{Co}$ alloys. Mater. Lett. 2014, 118, 111-114. [CrossRef]

62. Straumal, B.B.; Mazilkin, A.A.; Baretzky, B.; Rabkin, E.; Valiev, R.Z. Accelerated diffusion and phase transformations in Co-Cu alloys driven by the severe plastic deformation. Mater. Trans. 2012, 53, 63-71. [CrossRef]

63. Korneva, A.; Kogtenkova, O.; Protasova, S.; Straumal, B.; Mazilkin, A.; Kurmanaeva, L.; Zięba, P. Microstructure and magnetic properties of $\mathrm{Cu}-\mathrm{Co}$ alloys after high-pressure torsion. Inżyn. Materiat. 2013, 34, 306-309. [CrossRef]

64. Straumal, B.B.; Protasova, S.G.; Mazilkin, A.A.; Kogtenkova, O.A.; Kurmanaeva, L.; Baretzky, B.; Schütz, G.; Korneva, A.; Zięba, P. SPD-induced changes of structure and magnetic properties in the $\mathrm{Cu}-\mathrm{Co}$ alloys. Mater. Lett. 2013, 98, 217-221. [CrossRef]

65. Straumal, B.B.; Pontikis, V.; Kilmametov, A.R.; Mazilkin, A.A.; Dobatkin, S.V.; Baretzky, B. Competition between precipitation and dissolution in $\mathrm{Cu}-\mathrm{Ag}$ alloys under high pressure torsion. Acta Mater. 2017, 122, 60-71. [CrossRef]

66. Korneva, A.; Straumal, B.; Kilmametov, A.; Chulist, R.; Cios, G.; Baretzky, B.; Zięba, P. Dissolution of Ag precipitates in the $\mathrm{Cu}-8 \mathrm{wt} . \%$ Ag alloy deformed by high pressure torsion. Materials 2019, 12, 447. [CrossRef]

67. Straumal, B.B.; Kilmametov, A.R.; Kogtenkova, O.A.; Mazilkin, A.A.; Baretzky, B.; Korneva, A.; Zięba, P. Phase transitions in copper-silver alloys under high pressure torsion. Int. J. Mater. Res. 2019, 110, 608-613. [CrossRef]

68. Straumal, B.B.; Kilmametov, A.R.; Baretzky, B.; Kogtenkova, O.A.; Straumal, P.B.; Lityńska-Dobrzyńska, L.; Chulist, R.; Korneva, A.; Zięba, P. High pressure torsion of $\mathrm{Cu}-\mathrm{Ag}$ and $\mathrm{Cu}-\mathrm{Sn}$ alloys: Limits for solubility and dissolution. Acta Mater. 2020, 195, 184-198. [CrossRef]

69. Straumal, B.B.; Kilmametov, A.R.; Ivanisenko, Y.; Mazilkin, A.A.; Kogtenkova, O.A.; Kurmanaeva, L.; Korneva, A.; Zięba, P.; Baretzky, B. Phase transitions induced by severe plastic deformation: Steady-state and equifinality. Int. J. Mater. Res. 2015, 106, 657-664. [CrossRef]

70. Mazilkin, A.A.; Straumal, B.B.; Borodachenkova, M.V.; Valiev, R.Z.; Kogtenkova, O.A.; Baretzky, B. Gradual softening of Al-Zn alloys during high-pressure torsion. Mater. Lett. 2012, 84, 63-65. [CrossRef]

71. Straumal, B.B.; Baretzky, B.; Mazilkin, A.A.; Phillipp, F.; Kogtenkova, O.A.; Volkov, M.N.; Valiev, R.Z. Formation of nanograined structure and decomposition of supersaturated solid solution during high pressure torsion of Al-Zn and Al-Mg alloys. Acta Mater. 2004, 52, 4469-4478. [CrossRef]

72. Kormout, K.S.; Pippan, R.; Bachmaier, A. Deformation-induced supersaturation in immiscible material systems during highpressure torsion. Adv. Eng. Mater. 2017, 19, 1600675. [CrossRef] 
73. Kulagin, R.; Zhao, Y.; Beygelzimer, Y.; Toth, L.S.; Shtern, M. Modeling strain and density distributions during high-pressure torsion of pre-compacted powder materials. Mater. Res. Lett. 2017, 5, 179-186. [CrossRef]

74. Straumal, B.B.; Kilmametov, A.R.; Korneva, A.; Mazilkin, A.A.; Straumal, P.B.; Zięba, P.; Baretzky, B. Phase transitions in Cu-based alloys under high pressure torsion. J. Alloys Compd. 2017, 707, 20-26. [CrossRef]

75. Straumal, B.B.; Protasova, S.G.; Mazilkin, A.A.; Rabkin, E.; Goll, D.; Schütz, G.; Baretzky, B.; Valiev, R. Deformation-driven formation of equilibrium phases in the Cu-Ni alloys. J. Mater. Sci. 2012, 47, 360-367. [CrossRef]

76. Korneva, A.; Straumal, B.; Kogtenkova, O.; Ivanisenko, Y.; Kilmametov, A.; Wierzbicka-Miernik, A.; Zięba, P. Microstructure evolution of $\mathrm{Cu}-22 \%$ In alloy subjected to the high pressure torsion. IOP Conf. Ser. Mater. Sci. Eng. 2014, 63, 012093. [CrossRef]

77. Straumal, B.B.; Kilmametov, A.R.; Mazilkin, A.A.; Kurmanaeva, L.; Ivanisenko, Y.; Korneva, A.; Zięba, P.; Baretzky, B. Transformations of $\mathrm{Cu}(\mathrm{In})$ supersaturated solid solutions under high-pressure torsion. Mater. Lett. 2015, 138, 255-258. [CrossRef]

78. Korneva, A.; Straumal, B.; Kilmametov, A.; Chulist, R.; Straumal, P.; Zięba, P. Phase transformations in a Cu-Cr alloy induced by high pressure torsion. Mater. Charact. 2016, 114, 151-156. [CrossRef]

79. Beygelzimer, Y.; Kulagin, R.; Toth, L.S.; Ivanisenko, Y. The self-similarity theory of high pressure torsion. Beilstein J. Nanotechnol. 2016, 7, 1267-1277. [CrossRef]

80. Lee, S.; Horita, Z. High-pressure torsion for pure chromium and niobium. Mater. Trans. 2012, 53, 38-45. [CrossRef]

81. Edalati, K.; Akama, D.; Nishio, A.; Lee, S.; Yonenaga, Y.; Cubero-Sesin, J.M.; Horita, Z. Influence of dislocation-solute atom interactions and stacking fault energy on grain size of single-phase alloys after severe plastic deformation using high-pressure torsion. Acta Mater. 2014, 69, 68-77. [CrossRef]

82. Tejedor, R.; Edalati, K.; Benito, J.A.; Horita, Z.; Cabrera, J.M. High-pressure torsion of iron with various purity levels and validation of Hall-Petch strengthening mechanism. Mater. Sci. Eng. A 2019, 743, 597-605. [CrossRef]

83. Mohamed, I.F.; Masuda, T.; Lee, S.; Edalati, K.; Horita, Z.; Hirosawa, S.; Matsuda, K.; Terada, D.; Omar, M.Z. Strengthening of A2024 alloy by high-pressure torsion and subsequent aging. Mater. Sci. Eng. A 2017, 704, 112-118. [CrossRef]

84. Edalati, K.; Shao, H.; Emami, H.; Iwaoka, H.; Akiba, E.; Horita, Z. Activation of titanium-vanadium alloy for hydrogen storage by introduction of nanograins and edge dislocations using high-pressure torsion. Int. J. Hydrogen Energy 2016, 41, 8917-8924. [CrossRef]

85. Isik, M.; Niinomi, M.; Cho, K.; Nakai, M.; Liu, H.; Yilmazer, H.; Horita, Z.; Sato, S.; Narushima, T. Microstructural evolution and mechanical properties of biomedical Co-Cr-Mo alloy subjected to high-pressure torsion. J. Mech. Behav. Biomed. Mater. 2016, 59, 226-235. [CrossRef] [PubMed]

86. Isik, M.; Niinomi, M.; Liu, H.; Cho, K.; Nakai, M.; Horita, Z.; Sato, S.; Narushima, T.; Yilmazer, H.; Nagasako, M. Grain refinement mechanism and evolution of dislocation structure of $\mathrm{Co}-\mathrm{Cr}-\mathrm{Mo}$ alloy subjected to high-pressure torsion. Mater. Trans. 2016, 57, 1109-1118. [CrossRef]

87. Hongo, T.; Edalati, K.; Iwaoka, H.; Arita, M.; Matsuda, J.; Akiba, E.; Horita, Z. High-pressure torsion of palladium: Hydrogeninduced softening and plasticity in ultrafine grains and hydrogen-induced hardening and embrittlement in coarse grains. Mater. Sci. Eng. A 2014, 618, 1-8. [CrossRef]

88. Edalati, K.; Imamura, K.; Kiss, T.; Horita, Z. Equal-channel angular pressing and high-pressure torsion of pure copper: Evolution of electrical conductivity and hardness with strain. Mater. Trans. 2012, 53, 123-127. [CrossRef]

89. Hanna, A.; Azzeddine, H.; Lachha, R.; Baudin, T.; Helbert, A.-L.; Brisset, F.; Huang, Y.; Bradai, D.; Langdon, T.G. Evaluating the textural and mechanical properties of an Mg-Dy alloy processed by high-pressure torsion. J. Alloys Compd. 2019, 778, 61-71. [CrossRef]

90. Bourezg, Y.I.; Azzeddine, H.; Baudin, T.; Helbert, A.-L.; Huang, Y.; Bradai, D.; Langdon, T.G. Texture and microhardness of Mg-rare earth (Nd and Ce) alloys processed by high-pressure torsion. Mater. Sci. Eng. A 2018, 724, 477-485. [CrossRef]

91. Bazarnik, P.; Huang, Y.; Lewandowska, M.; Langdon, T.G. Enhanced grain refinement and microhardness by hybrid processing using hydrostatic extrusion and high-pressure torsion. Mater. Sci. Eng. A 2018, 712, 513-520. [CrossRef]

92. Cardona, D.M.M.; Wongsa-Ngam, J.; Jimenez, H.; Langdon, T.G. Effects on hardness and microstructure of AISI 1020 low-carbon steel processed by high-pressure torsion. J. Mater. Res. Technol. 2017, 6, 355-360. [CrossRef]

93. Korneva, A.; Straumal, B.; Chulist, R.; Kilmametov, A.; Bała, P.; Cios, G.; Schell, N.; Zięba, P. Grain refinement of intermetallic compounds in the $\mathrm{Cu}-\mathrm{Sn}$ system under high pressure torsion. Mater. Lett. 2016, 179, 12-15. [CrossRef]

94. Korneva, A.; Straumal, B.; Kilmametov, A.; Cios, G.; Bała, P.; Zięba, P. Effect of high pressure torsion on microstructure of Cu-Sn alloys with different content of Hume Rothery phase. Mater. Charact. 2016, 118, 411-416. [CrossRef]

95. Straumal, B.B.; Kilmametov, A.R.; Mazilkin, I.A.; Korneva, A.; Zięba, P.; Baretzky, B. Phase transformations in copper-tin solid solutions at high-pressure torsion. JETP Lett. 2019, 110, 624-628. [CrossRef]

96. Straumal, B.B.; Mazilkin, A.A.; Protasova, S.G.; Dobatkin, S.V.; Rodin, A.O.; Baretzky, B.; Goll, D.; Schütz, G. Fe-C nanograined alloys obtained by high pressure torsion: Structure and magnetic properties. Mater. Sci. Eng. A 2009, 503, 185-189. [CrossRef]

97. Sagaradze, V.V.; Shabashov, V.A. Deformation-induced anomalous phase transformations in nanocrystalline FCC Fe-Ni based alloys. Nanostruct. Mater. 1997, 9, 681-684. [CrossRef]

98. Murayama, M.; Hono, K.; Horita, Z. Microstructural evolution in an Al-1.7 at \%Cu alloy deformed by equal-channel angular pressing. Mater. Trans. JIM 1999, 40, 938-941. [CrossRef]

99. Ohsaki, S.; Kato, S.; Tsuji, N.; Ohkubo, T.; Hono, K. Bulk mechanical alloying of Cu-Ag and Cu/Zr two-phase microstructures by accumulative roll-bonding process. Acta Mater. 2007, 55, 2885-2895. [CrossRef] 
100. Sauvage, X.; Pippan, R. Nanoscaled structure of a Cu-Fe composite processed by high-pressure torsion. Mater. Sci. Eng. A 2005, 410, 345-347. [CrossRef]

101. Sauvage, X.; Genevois, C.; Da Costa, G.; Pantsyrny, V. Atomic scale characterization of deformation-induced interfacial mixing in a Cu/V nanocomposite wire. Scr. Mater. 2009, 61, 660-663. [CrossRef]

102. Sauvage, X.; Lefebvre, W.; Genevois, C.; Ohsaki, S.; Hono, K. Complementary use of transmission electron microscopy and atom probe tomography for the investigation of steels nanostructured by severe plastic deformation. Scr. Mater. 2009, 60, 1056-1061. [CrossRef]

103. Straumal, B.B.; Dobatkin, S.V.; Rodin, A.O.; Protasova, S.G.; Mazilkin, A.A.; Goll, D.; Baretzky, B. Structure and properties of nanograined Fe-C alloys after severe plastic deformation. Adv. Eng. Mater. 2011, 13, 463-469. [CrossRef]

104. Korznikov, A.V.; Dimitrov, O.; Korznikova, G.F.; Dallas, J.P.; Quivy, A.; Valiev, R.Z.; Mukherjee, A. Nanocrystalline structure and phase transformation of the intermetallic compound TiAl processed by severe plastic deformation. Nanostruct. Mater. 1999, 11, 17-23. [CrossRef]

105. Korznikov, A.V.; Tram, G.; Dimitrov, O.; Korznikova, G.F.; Idrisova, S.R.; Pakiela, Z. The mechanism of nanocrystalline structure formation in Ni3Al during severe plastic deformation. Acta Mater. 2001, 49, 663-671. [CrossRef]

106. Rentenberger, C.; Karnthaler, H.P. Extensive disordering in long-range-ordered Cu3Au induced by severe plastic deformation studied by transmission electron microscopy. Acta Mater. 2008, 56, 2526-2530. [CrossRef]

107. López, G.A.; López-Ferreño, I.; Kilmametov, A.R.; Breczewski, T.; Straumal, B.B.; Baretzky, B.; Nó, M.L.; San Juan, J. Severe plastic deformation on powder metallurgy Cu-Al-Ni shape memory alloys. Mater. Today Proc. 2015, 2S, S747-S750. [CrossRef]

108. Straumal, B.B.; Kilmametov, A.R.; López, G.A.; López-Ferreño, I.; Nó, M.L.; San Juan, J.; Hahn, H.; Baretzky, B. High-pressure torsion driven phase transformations in Cu-Al-Ni shape memory alloys. Acta Mater. 2017, 125, 274-285. [CrossRef]

109. Straumal, B.B.; Kilmametov, A.R.; Ivanisenko, Y.; Gornakova, A.S.; Mazilkin, A.A.; Kriegel, M.J.; Fabrichnaya, O.B.; Baretzky, B.; Hahn, H. Phase transformations in Ti-Fe alloys induced by high pressure torsion. Adv. Eng. Mater. 2015, 17, 1835-1841. [CrossRef]

110. Straumal, B.B.; Gornakova, A.S.; Mazilkin, A.A.; Fabrichnaya, O.B.; Kriegel, M.J.; Baretzky, B.; Jiang, J.-Z.; Dobatkin, S.V. Phase transformations in the severely plastically deformed $\mathrm{Zr}-\mathrm{Nb}$ alloys. Mater. Lett. 2012, 81, 225-228. [CrossRef]

111. Kilmametov, A.; Ivanisenko, Y.; Mazilkin, A.A.; Straumal, B.B.; Gornakova, A.S.; Fabrichnaya, O.B.; Kriegel, M.J.; Rafaja, D.; Hahn, H. The $\alpha \rightarrow \omega$ and $\beta \rightarrow \omega$ phase transformations in Ti-Fe alloys under high-pressure torsion. Acta Mater. 2018, 144, 337-351. [CrossRef]

112. Kriegel, M.J.; Kilmametov, A.; Rudolph, M.; Straumal, B.B.; Gornakova, A.S.; Stöcker, H.; Ivanisenko, Y.; Fabrichnaya, O.; Hahn, H.; Rafaja, D. Transformation pathway upon heating of Ti-Fe alloys deformed by high-pressure torsion. Adv. Eng. Mater. 2018, 20, 1700933. [CrossRef]

113. Tracy, C.L.; Park, S.; Rittman, D.R.; Zinkle, S.J.; Bei, H.; Lang, M.; Ewing, R.C.; Mao, W.L. High pressure synthesis of a hexagonal close-packed phase of the highentropy alloy CrMnFeCoNi. Nat. Commun. 2017, 8, 15634. [CrossRef]

114. Fujita, H.; Ueda, S. Stacking faults and f.c.c. $(\gamma) \rightarrow$ h.c.p. $(\epsilon)$ transformation in 188-type stainless steel. Acta Metall. 1972, 20, 759-767. [CrossRef]

115. Straumal, B.B.; Gornakova, A.S.; Fabrichnaya, O.B.; Kriegel, M.J.; Mazilkin, A.A.; Baretzky, B.; Gusak, A.M.; Dobatkin, S.V. Effective temperature of high pressure torsion in $\mathrm{Zr}-\mathrm{Nb}$ alloys. High Temp. Mater. Proc. 2012, 31, 339-350. [CrossRef]

116. Straumal, B.B.; Kilmametov, A.R.; Ivanisenko, Y.; Mazilkin, A.A.; Valiev, R.Z.; Afonikova, N.S.; Gornakova, A.S.; Hahn, H. Diffusive and displacive phase transitions in Ti-Fe and Ti-Co alloys under high pressure torsion. J. Alloys Compd. 2018, 735, 2281-2286. [CrossRef]

117. Shahmir, H.; Asghari-Rad, P.; Mehranpour, M.S.; Forghani, F.; Kim, H.S.; Nili-Ahmadabadi, M. Evidence of FCC to HCP and BCC-martensitic transformations in a CoCrFeNiMn high-entropy alloy by severe plastic deformation. Mater. Sci. Eng. A 2021, 807, 140875. [CrossRef]

118. Picak, S.; Yilmaz, H.C.; Karaman, I. Simultaneous deformation twinning and martensitic transformation in CoCrFeMnNi high entropy alloy at high temperatures. Scr. Mater. 2021, 202, 113995. [CrossRef]

119. Zhao, S.; Li, Z.; Zhu, C.; Yang, W.; Zhang, Z.; Armstrong, D.E.J.; Grant, P.S.; Ritchie, R.O.; Meyers, M.A. Amorphization in extreme deformation of the CrMnFeCoNi high-entropy alloy. Sci. Adv. 2021, 7, 3108. [CrossRef]

120. Glowka, K.; Zubko, M.; Swiec, P.; Prusik, K.; Albrecht, R.; Dercz, G.; Loskot, J.; Witala, B.; Stróz, D. Microstructure and mechanical properties of Co-Cr-Mo-Si-Y-Zr high entropy alloy. Metals 2020, 10, 1456. [CrossRef]

121. Campari, E.G.; Casagrande, A.; Colombini, E.; Gualtieri, M.L.; Veronesi, P. The effect of Zr addition on melting temperature, microstructure, recrystallization and mechanical properties of a Cantor high entropy alloy. Materials 2021, 14, 5994. [CrossRef] [PubMed]

122. Edalati, P.; Mohammadi, A.; Ketabchi, M.; Edalati, K. Ultrahigh hardness in nanostructured dual-phase high-entropy alloy $\mathrm{AlCrFeCoNiNb}$ developed by high-pressure torsion. J. Alloys Compd. 2021, 884, 161101. [CrossRef]

123. Chang, L.-S.; Straumal, B.B.; Rabkin, E.; Gust, W.; Sommer, F. The solidus line of the Cu-Bi phase diagram. J. Phase Equil. 1997, 18, 128-135. [CrossRef]

124. Straumal, B.B.; Baretzky, B. Grain boundary phase transitions and their influence on properties of polycrystals. Interf. Sci. 2004, 12, 147-155. [CrossRef]

125. Rabkin, E.I.; Shvindlerman, L.S.; Straumal, B.B. Grain boundaries: Phase transitions and critical phenomena. Int. J. Mod. Phys. B 1991, 5, 2989-3028. [CrossRef] 
126. Straumal, B.B.; Korneva, A.; Kuzmin, A.; Lopez, G.; Rabkin, E.; Straumal, A.B.; Gerstein, G.; Gornakova, A.S. The grain boundary wetting phenomena in the Ti-containing high entropy alloys: A review. Metals 2021, 11, 1881. [CrossRef]

127. Straumal, B.B.; Korneva, A.; Lopez, G.A.; Kuzmin, A.; Rabkin, E.; Gerstein, G.; Straumal, A.B.; Gornakova, A.S. Grain boundary wetting by a second solid phase in the high entropy alloys: A review. Materilas 2021, 14, 7506. [CrossRef]

128. Straumal, A.B.; Tsoy, K.V.; Mazilkin, I.A.; Nekrasov, A.N.; Bryła, K. Grain boundary wetting and material performance in an industrial EZ33A Mg cast alloy. Arch. Metall. Mater. 2019, 64, 869-873. [CrossRef]

129. Edalati, P.; Mohammadi, A.; Tang, Y.; Floriano, R.; Fuji, M.; Edalati, K. Phase transformation and microstructure evolution in ultrahard carbon-doped AlTiFeCoNi high-entropy alloy by high-pressure torsion. Mater. Lett. 2021, 302, 130368. [CrossRef]

130. Asghari-Rad, P.; Nguyen, N.T.-C.; Zargaran, A.; Sathiyamoorthi, P.; Kim, H.S. Deformation-induced grain boundary segregation mediated high-strain rate superplasticity in medium entropy alloy. Scr. Mater. 2022, 207, 114239. [CrossRef]

131. Korznikov, A.V.; Ivanisenko, Y.V.; Laptionok, D.V.; Safarov, I.M.; Pilyugin, V.P.; Valiev, R.Z. Influence of severe plastic deformation on structure and phase composition of carbon steel. Nanostruct. Mater. 1994, 4, 159-167. [CrossRef]

132. Ivanisenko, Y.; Lojkowski, W.; Valiev, R.Z.; Fecht, H.-J. Formation of nanostructure and dissolution of cementite in a pearlitic steel during high pressure torsion. Acta Mater. 2003, 51, 5555-5570. [CrossRef]

133. Ivanisenko, Y.; Wunderlich, R.K.; Valiev, R.Z.; Fecht, H.-J. Annealing behaviour of nanostructured carbon steel produced by severe plastic deformation. Scr. Mater. 2003, 49, 947-952. [CrossRef]

134. Mazilkin, A.A.; Straumal, B.B.; Kilmametov, A.R.; Boll, T.; Baretzky, B.; Kogtenkova, O.A.; Korneva, A.; Zięba, P. Competition for impurity atoms between defects and solid solution during high pressure torsion. Scr. Mater. 2019, 173, 46-50. [CrossRef]

135. Ivanisenko, Y.; Sauvage, X.; Mazilkin, A.; Kilmametov, A.; Beach, J.A.; Straumal, B.B. Bulk nanocrystalline ferrite stabilized through grain boundary carbon segregation. Adv. Eng. Mater. 2018, 20, 1800443. [CrossRef]

136. Straumal, B.B.; Mazilkin, A.A.; Protasova, S.G.; Myatiev, A.A.; Straumal, P.B.; Baretzky, B. Increase of Co solubility with decreasing grain size in ZnO. Acta Mater. 2008, 56, 6246-6256. [CrossRef]

137. Straumal, B.B.; Baretzky, B.; Mazilkin, A.A.; Protasova, S.G.; Myatiev, A.A.; Straumal, P.B. Increase of Mn solubility with decreasing grain size in ZnO. J. Eur. Ceram. Soc. 2009, 29, 1963-1970. [CrossRef]

138. Straumal, B.B.; Mazilkin, A.A.; Protasova, S.G.; Straumal, P.B.; Myatiev, A.A.; Schütz, G.; Goering, E.; Baretzky, B. Ferromagnetism of nanostructured zinc oxide films. Phys. Metal. Metallogr. 2012, 113, 1244-1256. [CrossRef]

139. Straumal, B.B.; Protasova, S.G.; Mazilkin, A.A.; Schütz, G.; Goering, E.; Baretzky, B.; Straumal, P.B. Ferromagnetism of zinc oxide nanograined films. JETP Lett. 2013, 97, 367-377. [CrossRef]

140. Protasova, S.G.; Straumal, B.B.; Mazilkin, A.A.; Stakhanova, S.V.; Straumal, P.B.; Baretzky, B. Increase of Fe solubility in ZnO induced by the grain boundary adsorption. J. Mater. Sci. 2014, 49, 4490-4498. [CrossRef]

141. Straumal, B.B.; Mazilkin, A.A.; Protasova, S.G.; Stakhanova, S.V.; Straumal, P.B.; Bulatov, M.F.; Schütz, G.; Tietze, T.; Goering, E.; Baretzky, B. Grain boundaries as a source of ferromagnetism and increased solubility of Ni in nanograined ZnO. Rev. Adv. Mater. Sci. 2015, 41, 61-71.

142. Straumal, B.B.; Protasova, S.G.; Mazilkin, A.A.; Goering, E.; Schütz, G.; Straumal, P.B.; Baretzky, B. Ferromagnetic behaviour of ZnO: Role of grain boundaries. Beilstein J. Nanotechnol. 2016, 7, 1936-1947. [CrossRef]

143. Edalati, P.; Mohammadi, A.; Ketabchi, M.; Edalati, K. Microstructure and microhardness of dual-phase high-entropy alloy by high-pressure torsion: Twins and stacking faults in FCC and dislocations in BCC. J. Alloys Compd. 2021, 894, 162413. [CrossRef]

144. Lukác, F.; Dudra, M.; Cížek, J.; Harcuba, P.; Vlasák, T.; Janecek, M.; Kuriplach, J.; Moon, J.; Kim, H.S.; Zýka, J.; et al. Defects in high entropy alloy HfNbTaTiZr prepared by high pressure torsion. Acta Phys. Polon. A 2018, 134, 891-894. [CrossRef]

145. Kilmametov, A.; Kulagin, R.; Mazilkin, A.; Seils, S.; Boll, T.; Heilmaier, M.; Hahn, H. High-pressure torsion driven mechanical alloying of CoCrFeMnNi high entropy alloy. Scr. Mater. 2019, 158, 29-33. [CrossRef]

146. Sathiyamoorthi, P.; Bae, J.W.; Asghari-Rad, P.; Park, J.M.; Kim, J.G.; Kim, H.S. Effect of annealing on microstructure and tensile behavior of CoCrNi medium entropy alloy processed by high-pressure torsion. Entropy 2018, 20, 849. [CrossRef] [PubMed]

147. Maksimova, E.L.; Shvindlerman, L.S.; Straumal, B.B. Transformation of $\Sigma 17$ special tilt boundaries to general boundaries in tin. Acta Metall. 1988, 36, 1573-1583. [CrossRef]

148. Straumal, B.B.; Polyakov, S.A.; Mittemeijer, E.J. Temperature influence on the faceting of $\Sigma 3$ and $\Sigma 9$ grain boundaries in Cu. Acta Mater. 2006, 54, 167-172. [CrossRef]

149. Molodov, D.A.; Czubayko, U.; Gottstein, G.; Shvindlerman, L.S.; Straumal, B.B.; Gust, W. Acceleration of grain boundary motion in Al by small additions of Ga. Phil. Mag. Lett. 1995, 72, 361-368. [CrossRef]

150. Li, W.; Fan, H.; Tang, J.; Wang, Q.; Zhang, X.; El-Awady, J.A. Effects of alloying on deformation twinning in high entropy alloys. Mater. Sci. Eng. A 2019, 763, 138143. [CrossRef]

151. Rogal, L.; Wdowik, U.D.; Szczerba, M.; Yurchenko, N.; Czeppe, T.; Bobrowski, P. Deformation induced twinning in hcp/bcc $\mathrm{Al}_{10} \mathrm{Hf}_{25} \mathrm{Nb}_{5} \mathrm{Sc}_{10} \mathrm{Ti}_{25} \mathrm{Zr}_{25}$ high entropy alloy-microstructure and mechanical properties. Mater. Sci. Eng. A 2021, 802, 140449. [CrossRef]

152. Yang, S.; Yang, Y. Thermodynamics-kinetics of twinning/martensitic transformation in $\mathrm{Fe}_{50} \mathrm{Mn}_{30} \mathrm{Co}_{10} \mathrm{Cr}_{10}$ high-entropy alloy during adiabatic shearing. Scr. Mater. 2020, 181, 115-120. [CrossRef]

153. Ernst, F.; Finnis, M.W.; Koch, A.; Schmidt, C.; Straumal, B.; Gust, W. Structure and energy of twin boundaries in copper. Z. Metallk. 1996, 87, 911-922. 
154. Straumal, B.B.; Polyakov, S.A.; Bischoff, E.; Gust, W.; Mittemeijer, E.J. Faceting of $\Sigma 3$ and $\Sigma 9$ grain boundaries in copper. Interface Sci. 2001, 9, 287-292. [CrossRef]

155. Sursaeva, V.G.; Straumal, B.B.; Gornakova, A.S.; Shvindlerman, L.S.; Gottstein, G. Effect of faceting on grain boundary motion in Zn. Acta Mater. 2008, 56, 2728-2734. [CrossRef]

156. Yoshida, S.; Ikeuchi, T.; Bai1, Y.; Tsuji, N. Effect of cobalt-content on mechanical properties of non-equiatomic CoCrNi medium entropy alloys. Mater. Trans. 2020, 61, 587-595. [CrossRef]

157. Wang, S.; Wu, D.; She, H.; Wu, M.; Shu, D.; Dong, A.; Lai, H.; Sun, B. Design of high-ductile medium entropy alloys for dental implants. Mater. Sci. Eng. C 2020, 113, 110959. [CrossRef]

158. Wang, S.; Wu, M.; Shu, D.; Zhu, G.; Wang, D.; Sun, B. Mechanical instability and tensile properties of TiZrHfNbTa high entropy alloy at cryogenic temperatures. Acta Mater. 2020, 201, 517-527. [CrossRef]

159. Straumal, B.B.; Kogtenkova, O.A.; Gornakova, A.S.; Sursaeva, V.G.; Baretzky, B. Review: Grain boundary faceting-roughening phenomena. J. Mater. Sci. 2016, 51, 382-404. [CrossRef]

160. Straumal, B.B.; Polyakov, S.A.; Bischoff, E.; Gust, W.; Baretzky, B. Faceting of $\Sigma 3$ and $\Sigma 9$ grain boundaries in Cu-Bi alloys. Acta Mater. 2005, 53, 247-254. [CrossRef]

161. Gubicza, J.; Heczel, A.; Kawasaki, M.; Han, J.-K.; Zhao, Y.; Xue, Y.; Huang, S.; Lábár, J.L. Evolution of microstructure and hardness in $\mathrm{Hf}_{25} \mathrm{Nb}_{25} \mathrm{Ti}_{25} \mathrm{Zr}_{25}$ high-entropy alloy during high-pressure torsion. J. Alloys Compd. 2019, 788, 318-328. [CrossRef]

162. Č́í̌̌ek, J.; Haušild, P.; Cieslar, M.; Melikhova, O.; Vlasák, T.; Janeček, M.; Král, R.; Harcuba, P.; Lukáč, F.; Zýka, J.; et al. Strength enhancement of high entropy alloy HfNbTaTiZr by severe plastic deformation. J. Alloys Compd. 2018, 768, 924-937. [CrossRef]

163. Schuh, B.; Völker, B.; Todt, J.; Schell, N.; Perrière, L.; Li, J.; Couzinié, J.P.; Hohenwarter, A. Thermodynamic instability of a nanocrystalline, single-phase TiZrNbHfTa alloy and its impact on the mechanical properties. Acta Mater. 2018, 142, 201-212. [CrossRef]

164. Jeong, H.T.; Kim, W.J. Microstructure tailoring of $\mathrm{Al}_{0.5} \mathrm{CoCrFeMnNi}$ to achieve high strength and high uniform strain using severe plastic deformation and an annealing treatment. J. Mater. Sci. Technol. 2021, 71, 228-240. [CrossRef]

165. Wu, W.; Song, M.; Ni, S.; Wang, J.; Liu, Y.; Liu, B.; Liao, X. Dual mechanisms of grain refinement in a FeCoCrNi high entropy alloy processed by high pressure torsion. Sci. Rep. 2017, 7, 46720. [CrossRef]

166. Shahmir, H.; He, J.; Lu, Z.; Kawasaki, M.; Langdon, T.G. Evidence for superplasticity in a CoCrFeNiMn high-entropy alloy processed by high-pressure torsion. Mater. Sci. Eng. A 2017, 685, 342-348. [CrossRef]

167. Yuan, H.; Tsai, M.-H.; Sha, G.; Liu, F.; Horita, Z.; Zhu, Y.; Wang, J.T. Atomic-scale homogenization in an fcc-based high-entropy alloy via severe plastic deformation. J. Alloys Compd. 2016, 686, 15-23. [CrossRef]

168. Skrotzki, W.; Pukenas, A.; Odor, E.; Joni, B.; Ungar, T.; Völker, B.; Hohenwarter, A.; Pippan, R.; George, E.P. Microstructure, texture, and strength development during high-pressure torsion of CrMnFeCoNi high-entropy alloy. Crystals 2020, 10, 336. [CrossRef]

169. Schuh, B.; Völker, B.; Todt, J.; Kormout, K.S.; Schell, N.; Hohenwarter, A. Influence of annealing on microstructure and mechanical properties of a nanocrystalline CrCoNi medium-entropy alloy. Materials 2018, 11, 662. [CrossRef]

170. Schuh, B.; Völker, B.; Maier-Kiener, V.; Todt, J.; Li, J.; Hohenwarter, A. Phase decomposition of a single-phase AlTiVNb highentropy alloy after severe plastic deformation and annealing. Adv. Eng. Mater. 2017, 19, 1600674. [CrossRef]

171. Sarkar, S.; Sarswat, P.K.; Free, M.L. Elevated temperature corrosion resistance of additive manufactured single phase AlCoFeNiTiV ${ }_{0.9} \mathrm{Sm}_{0.1}$ and $\mathrm{AlCoFeNiV}_{0.9} \mathrm{Sm}_{0.1}$ HEAs in a simulated syngas atmosphere. Add. Manuf. 2019, 30, 100902. [CrossRef]

172. Sarswat, P.K.; Sarkar, S.; Murali, A.; Huang, W.; Tan, W.; Free, M.L. Additive manufactured new hybrid high entropy alloys derived from the AlCoFeNiSmTiVZr system. Appl. Surf. Sci. 2019, 476, 242-258. [CrossRef]

173. Sarswat, P.; Smith, T.; Sarkar, S.; Murali, A.; Free, M. Design and fabrication of new high entropy alloys for evaluating titanium replacements in additive manufacturing. Materials 2020, 13, 3001. [CrossRef] [PubMed]

174. Oses, C.; Toher, C.; Curtarolo, S. High-entropy ceramics. Nat. Rev. Mater. 2020, 5, 295-309. [CrossRef]

175. Straumal, B.; Rabkin, E.; Lopez, G.A.; Korneva, A.; Kuzmin, A.; Gornakova, A.S.; Valiev, R.Z.; Straumal, A.; Baretzky, B. Grain boundary wetting phenomena in the high entropy alloys containing nitrides, carbides, borides, silicides, and hydrogen: A review. Crystals 2021, 11, 1540. [CrossRef] 